\title{
O MESTRADO PROFISSIONAL EM PROJETO E PATRIMÔNIO DO PROARQ/FAU/UFRJ
}

\author{
RIBEIRO, ROSINA TREVISAN M. \\ Professora, Doutora; Coordenadora do Mestrado Profissional em Projeto e Patrimônio; e-mail: rosinatrevisan@gmail.com
}

NÓBREGA, CLAUDIA CARVALHO LEME

Professora, Doutora, Vice-Coordenadora do Mestrado Profissional em Projeto e Patrimônio; e-mail: claudiaclnobrega@gmail.com

\section{INTRODUÇÃO}

A política de educação continuada difundida pela CAPES tem como um de seus objetivos identificar necessidades de formação e de desenvolvimento dos profissionais e construir estratégias e processos que qualifiquem o profissional, na perspectiva de produzir impacto positivo sobre o meio ambiente e a sociedade. Procura articular educação e trabalho partindo do pressuposto de que a transformação das práticas profissionais está baseada na reflexão crítica sobre os problemas reais do dia a dia dos profissionais.

Com isto, o Mestrado Profissional tem um papel importante na formação de conhecimento aplicado à demanda do mercado, atendendo exigências do avanço tecnológico e da reflexão do profissional sobre as questões do mundo atual, visando a melhoria da qualidade do trabalho.

\section{O CURSO DE MESTRADO PROFISSIONAL EM PROJETO E PATRIMÔNIO DA UFRJ}

Os projetos em áreas preservadas aumentam a cada dia. A faculdade de arquitetura não oferece disciplinas suficientes para um conhecimento mais aprofundado sobre o assunto e, com isto, vem a necessidade de um maior conhecimento por parte de recém-formados, que representam o maior grupo que procuram o curso de Mestrado Profissional em Projeto e Patrimônio da UFRJ. As especificidades de um projeto de restauro necessitam de um estudo e um entendimento muito maior daquele fornecido na graduação. Segundo Mario Mendonça, "há que se destacar que o restauro do patrimônio edificado, em um particular, coincide com o exercício da arquitetura contemporânea. É um mister que se fundamenta na teoria e na prática, binômio que é ponto de partida para o exercício da atividade de todos os bons profissionais" (OLIVEIRA, 2003).

O curso de Mestrado Profissional em Projeto e Patrimônio, proposto pelo Programa de Pós-Graduação em Arquitetura (PROARQ) da Faculdade de Arquitetura e Urbanismo da Universidade Federal do Rio de Janeiro (FAU/UFRJ), objetiva a formação de Mestres, em nível stricto-sensu, no que diz respeito à necessidade de interpretar, registrar e intervir no patrimônio cultural edificado no campo da arquitetura e urbanismo, tendo em vista a realização de:

- $\quad$ projetos de intervenção, visando a restauração e revitalização com proposição de novos usos e novas formas arquitetônicas, incluindo edificações e ambientes urbanos;

- $\quad$ projetos de gestão e sustentabilidade com pesquisa para o desenvolvimento de técnicas de conservação e restauração deste patrimônio.

O curso pretende contribuir para o aprofundamento da prática profissional, visando a preservação do patrimônio cultural e suas diversas interfaces interdisciplinares relacionadas com a concepção, com a produção, a gestão e a qualidade do ambiente construído.

O Mestrado Profissional em Projeto e Patrimônio veio atender a um setor do mercado de trabalho que necessita de pessoas especializadas na área de projetos relacionados ao patrimônio cultural edificado. $O$ público alvo do curso inclui profissionais vinculados a instituições e órgãos públicos; a empresas privadas e de economia mista; profissionais do ensino superior e profissionais liberais. 
Neste sentido, o curso fornece aos mestrandos instrumentos da história, da teoria crítica e da técnica que os capacitem a conservar, revitalizar, restaurar os bens culturais edificados, bem como identificar e promover inovações teórico-metodológicas e sua aplicação na prática do projeto de intervenção em edificações e sítios urbanos, contribuindo para o aprofundamento da prática profissional e suas diversas interfaces interdisciplinares relacionadas com a concepção, com a produção, a gestão e a qualidade do ambiente construído. Com duração de 24 meses, o curso é voltado para profissionais com diploma de graduação na área de Arquitetura e Urbanismo.

Muitos aspectos da formação específica do arquiteto-urbanista para atuar nas questões do patrimônio cultural edificado são abordadas na graduação de forma incipiente. A faculdade oferece apenas uma disciplina obrigatória relacionada a questões do patrimônio cultural e mesmo assim sem se aprofundar nos conceitos teóricos de preservação do patrimônio. No caso da FAU/UFRJ, existe mais uma disciplina eletiva de Projeto Executivo de Restauro que é oferecida em um período, tempo insuficiente para a proposta do programa de curso. Existem questões de documentação, representação, conhecimento dos materiais de construção históricos, aspectos simbólicos e culturais que constituem ferramental básico do projeto para o patrimônio cultural e que não são discutidas durante a graduação.

O Rio de Janeiro possui um patrimônio histórico muito rico, com centenas de edificações tombadas a nível Federal, Estadual e Municipal. Foi o polo da criação do patrimônio nacional na década de 1930 quando foi criado o órgão nacional responsável pela preservação do patrimônio brasileiro, 0 atual Instituto do Patrimônio Histórico e Artístico Nacional. A nível estadual temos o INEPAC - Instituto Estadual do Patrimônio Cultural e na esfera municipal temos o IRPH - Instituto Rio Patrimônio da Humanidade, onde teve início, no início da década de 1980, o projeto do Corredor Cultural, pioneiro em preservação de áreas históricas. A cidade possui mais de trinta Áreas de Proteção do Ambiente Construído (APAC), abrangendo 35 (trinta e cinco) bairros com mais de 700 imóveis tombados e cerca de 10 mil imóveis protegidos. Além disto, existem mais de 1700 bens tombados localizados fora das áreas das APACs. Consequentemente a demanda por profissionais qualificados é grande.

A estrutura acadêmica do Mestrado Profissional em Projeto e Patrimônio da UFRJ tem a maior parte do corpo docente do PROARQ - Programa de Pós-Graduação em Arquitetura participando do Mestrado Profissional. Dos 16 (dezesseis) professores do quadro permanente e de colaboradores do Mestrado Profissional, 3 (três) são externos à UFRJ (19\%) em função da larga experiência na área de Patrimônio e Projeto.

O curso é composto por uma área de concentração em 'Projeto e Patrimônio Cultural' e duas Linhas de Pesquisa: (1) Projeto, Gestão e Sustentabilidade do Patrimônio e (2) Projeto de Revitalização e Restauração. As disciplinas são direcionadas às questões de projeto na área de preservação do patrimônio cultural, com 240 horas obrigatórias de Ateliê (67\% da carga horária mínima) e o restante da carga horária distribuída nas demais disciplinas que colaboram com a fundamentação teórica necessária ao desenvolvimento dos projetos relacionados à questão do patrimônio.

Atualmente, os candidatos que participam do processo seletivo ao Mestrado Profissional em Projeto e Patrimônio precisam apresentar uma Proposta de Estudo a ser desenvolvida durante o curso. Esta Proposta de Estudo a ser apresentada para a seleção deve contemplar a indicação do edifício ou núcleo urbano a ser trabalhado, indicando a importância de se recuperar - através de um processo de conservação, restauração, revitalização, requalificação - o edifício ou sítio urbano escolhido como tema de investigação e de trabalho, ou, a necessidade de inserção de uma nova edificação no sítio preservado. $O$ objeto arquitetônico ou urbano tem que ter relevância cultural (histórica, arqueológica, artística, etc.).

Ao longo dos seus três anos e meio de funcionamento, o Mestrado Profissional em Projeto e Patrimônio vem se aprimorando, tentando adequar suas disciplinas ao seu público alvo, os alunos.

Atualmente as disciplinas de Ateliê, que possuem maior carga horária são estruturadas da seguinte forma:

- Ateliê 1 - o trabalho é desenvolvido tendo como base o objeto de estudo do aluno, seja ele uma edificação ou um sítio histórico. É realizada toda etapa de diagnóstico do bem em conjunto com as disciplinas eletivas.

- Ateliê 2 - os alunos trabalham com a área imediatamente ao redor do seu objeto de estudo - área de entorno.

- Ateliê 3 - o trabalho é desenvolvido no território onde o objeto de estudo do aluno se localiza, com propostas projetual de intervenção nesta área.

- Ateliê 4 - estudo e desenvolvimento da dissertação, com aprofundamento teórico-metodológico do trabalho final do aluno.

Inserimos no curso um convênio com órgãos de patrimônio, tais como o IPHAN - Instituto do Patrimônio Histórico e Artístico Nacional na turma de 2015, e o INEPAC - Instituto Estadual do Patrimônio Artístico e 
Cultural do Rio de Janeiro na turma de 2016. Através destes convênios, técnicos destes órgãos cursam o Mestrado Profissional conosco e podem repassar toda sua experiência prática para os demais alunos.

\section{RESULTADOS OBTIDOS}

O Mestrado Profissional em Projeto e Patrimônio teve sua primeira turma iniciada em setembro de 2013. Até o momento, junho/2017, apenas duas turmas concluíram seu prazo de defesa das dissertações. A $1 \stackrel{\text { a turma }}{ }$ teve seis dissertações defendidas e na segunda turma foram sete dissertações. Logo, até o momento, foram atribuídos o grau de Mestre em Projeto e Patrimônio a 13 (treze) pós-graduandos. Os temas iniciais destas dissertações se referem a projetos em geral, relacionados à área do patrimônio arquitetônico. A partir da turma de 2015 passamos a exigir que em todas as dissertações fossem desenvolvidos projetos (arquitetônicos) na área de patrimônio cultural, quer sejam projetos de restauração, conservação, revitalização, reabilitação de edificações ou núcleos históricos, ou mesmo a inserção de projetos contemporâneos em sítios de interesse de preservação.

Exibiremos aqui seis propostas defendidas no Mestrado Profissional em Projeto e Patrimônio com os resumos expandidos elaborados pelos próprios autores, em ordem alfabética.

\section{REFERÊNCIAS}

CAPES. Portaria Normativa No 17, de 28 de dezembro de 2009, dispõe sobre o Mestrado Profissional no âmbito da CAPES. Disponível em http://www.capes.gov.br/images/stories/download/avaliacao/avaliacao-n/Portaria-MEC-172009.pdf

OLIVEIRA, Mário Mendonça de. A ciência, a prática e a projetação do restauro. In: Actas do III ENCORE. Lisboa, 26-30 nov 2003. Anais... Lisboa: Laboratório Nacional de Engenharia Civil, 2003, p. 63-72.

NOTA DO EDITOR $\left({ }^{*}\right)$ O conteúdo do artigo e as imagens nele publicadas são de responsabilidade do(s) autor(es). 


\title{
ALÉM DA ROTA ACESSÍVEL: PROJETO DE ACESSIBILIDADE APLICADO À REVITALIZAÇÃO DO PATRIMÔNIO CONSOLIDADO DO INSTITUTO BENJAMIN CONSTANT
}

\author{
SILVA, ANDRÉ FERNANDES GOMES DA \\ Arquiteto e Urbanista, MsC., sócio proprietário da André Fernandes Arquitetura e Urbanismo Ltda; email: andre.fgs@gmail.com \\ Dissertação desenvolvida no Mestrado Profissional em Projeto e Patrimônio. PROARQ/UFRJ - \\ Programa de Pós-graduação em Arquitetura da Universidade Federal do Rio de Janeiro. \\ Orientadora: Ethel Pinheiro Santana
}

\section{RESUMO EXPANDIDO}

O tema deste trabalho trata a relação entre patrimônio e acessibilidade, revitalização e restauração do patrimônio edificado, com fundamentação teórica e metodologia científica visando à análise mais aprofundada e discussão projetual para o Instituto Benjamin Constant-IBC. A escolha do tema está relacionada à experiência prática profissional do autor como arquiteto, à vivência desafiadora de projetar e apresentar as devidas justificativas para a implantação de elementos que contribuem para a acessibilidade e melhor qualidade de vida para pessoas com deficiência.

As relações entre o patrimônio cultural edificado e sua adaptação física para pessoas com deficiência é um tema que ainda merece maior destaque no exercício profissional do arquiteto e nos cursos de arquitetura. Apesar de regido por leis federais (LF o 10.048/2000, LF oㅜ 10.098/2000, ABNT NBR 9050 de 2015) e por diversas sanções de ordem estadual e municipal, o processo de adaptação/reforma de espaços físicos consolidados, para que sejam acessíveis para pessoas com deficiência, ainda é moroso, complicado e bastante protelado diante das dificuldades inerentes ao exercício de compatibilização entre a forma como é tratada às necessidades de conservação de um bem patrimonial e o direito de ir-e-vir de todos os cidadãos.

As afirmações do Relatório da OMS sobre a deficiência constituem uma importante referência para a construção do perfil de público dos ambientes construídos em um futuro próximo, e embora a evolução da ciência e tecnologia sejam importantes aliadas na superação das limitações físicas dos seres humanos, as atividades desempenhadas por arquitetos não devem direcionar-se apenas para um modelo pré-concebido de corpo jovem com funções corporais em plena forma, assim como não devem ser apoiadas apenas em aparatos virtuais (da ordem do possível) e deixar de lado as demais esferas sensoriais que abarcam todas as atividades humanas.

As propostas de Le Corbusier foram de grande importância para a arquitetura, e muitos arquitetos tomaram como referência os modelos criados por ele para o dimensionamento dos ambientes projetados para os seres humanos. Atualmente, as Normas Técnicas da Associação Brasileira de Normas Técnicas - ABNT apresentam parâmetros antropométricos e módulos de referência de pessoas com cadeiras de rodas, pessoas que usam muletas, e pessoas que usam bengalas, oferecendo aos arquitetos ferramentas mais realistas no que se refere à diversidade de características físicas do público à que se destinam as obras arquitetônicas.

De acordo com a Convenção das Nações Unidas sobre os Direitos das Pessoas com Deficiência - CDPD de 2006, a deficiência é um conceito em evolução e está diretamente relacionada às barreiras comportamentais/atitudinais e ambientais que impedem a participação plena e eficaz das pessoas com deficiência na sociedade de forma igualitária.

A prática profissional do arquiteto leva a uma objetiva constatação de que as dimensões físicas dos ambientes são os verdadeiros limitadores na implantação das adaptações para a acessibilidade previstas nas Normas Técnicas. Em projetos relacionados à restauração de edificações, os limites da proposta de intervenção são fortemente influenciados pela não descaracterização do bem por meio da preservação da autenticidade, da unidade potencial como patrimônio cultural, e a referência básica que trata da preservação do patrimônio é a Instrução Normativa do IPHAN no1 de 25 de novembro de 2003 que estabelece diretrizes, critérios e recomendações para a promoção das devidas condições de acessibilidade aos bens culturais imóveis. No entanto, diversas pesquisas lideradas por grupos sediados no Brasil e no exterior, entre eles o Núcleo Pro-acesso/PROARQ, indicam que a maior barreira, e talvez a principal, é a atitudinal, o que 
corrobora com nossas colocações iniciais sobre a necessidade de apreciação de outros conceitos (como a atenção aos quesitos de ordem sensorial e emocional) para a apresentação de propostas mais abrangentes para a adaptação dos espaços físicos, no campo da acessibilidade. Ou seja, ir além dos critérios preestabelecidos em normatizações.

O autor realizou vasta pesquisa sobre o Instituto Benjamin Constant - IBC, que há mais de 150 anos tem como foco o atendimento de pessoas com deficiência visual, que frequentam, diariamente, o Instituto para tratamento médico, reabilitação, estudo fundamental e médio, prática de esportes ou trabalho. Ao estudarmos o IBC nos deparamos com a realidade e o cotidiano de pessoas que aprenderam a não depender do sentido da visão para interagir com o mundo ao seu redor. Estas pessoas percebem os ambientes construídos por meio dos sons, circulação do ar, cheiros e tato, e assim precisamos entender como essas pessoas com deficiência visual percebem os ambientes que frequentam e 0 que passa despercebido, como uma mera sensação de algo além de sua percepção, qual sua consciência de patrimônio, e entender quais são as barreiras que enfrentam para o pleno uso dos ambientes construídos e sua inclusão social.

Além do levantamento documental, parte da metodologia foi composta pela aplicação de questionários semi-estruturados, entrevistando voluntários com deficiência visual. Além das entrevistas foram realizadas observações utilizando como base a metodologia dos Percursos Comentados de Jean Paul Thibaud (2001) (Figuras 1 e 2). Assim, foi possível construir um plano de necessidades que serviu como norte para 0 projeto de intervenção.

A pergunta fundamental que orientou a construção da metodologia da pesquisa e construção da proposta de intervenção foi: $E$ o que seria ir além do quesito estrito de acessibilidade nos ambientes para pessoas com deficiência?

Figura 1: Mapa indicativo dos sentimentos manifestados pelos voluntários cegos durante a aplicação do Percurso Comentado.

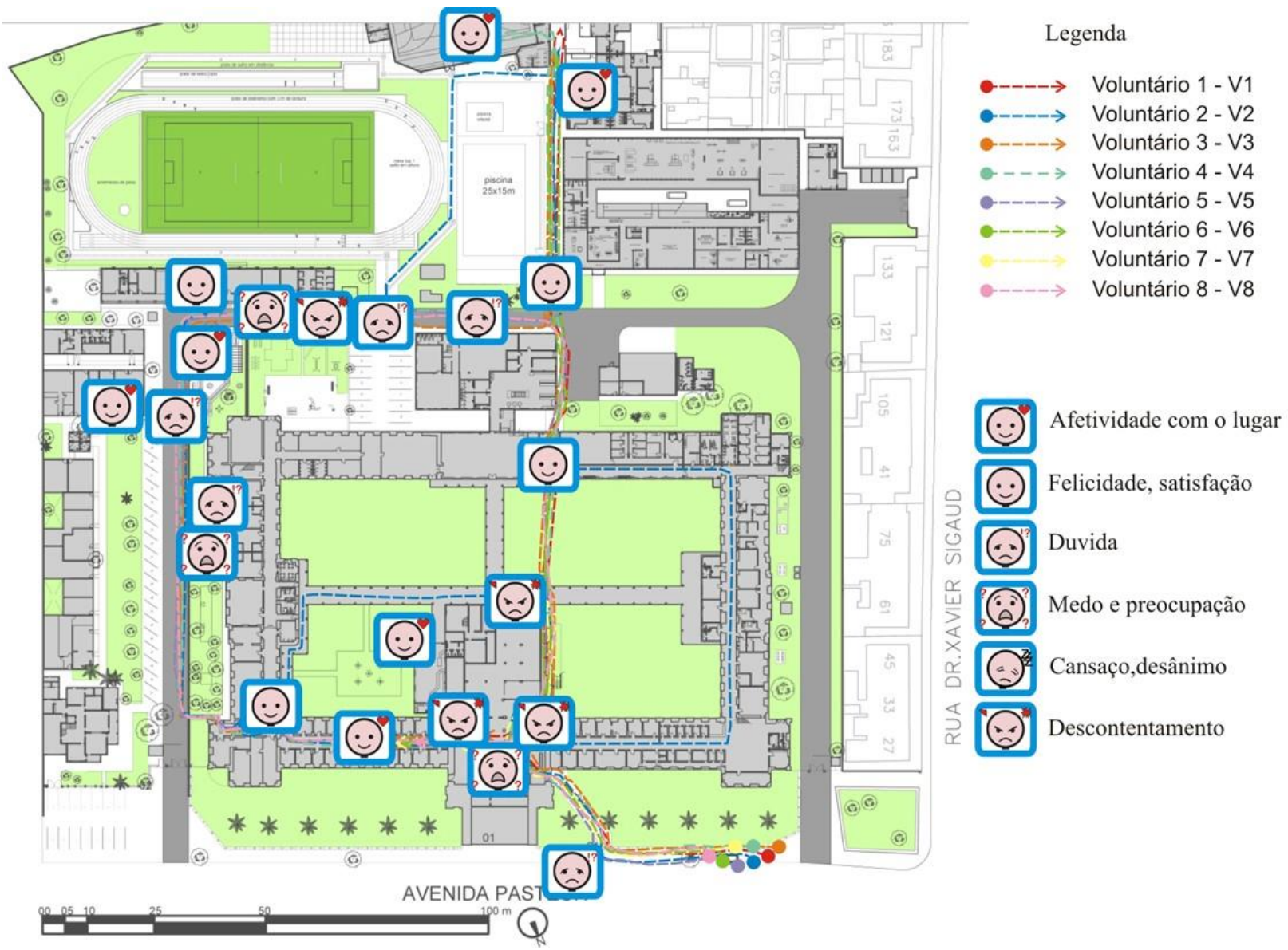

Fonte: O autor, 2015. 
Figura 2: Parte do percurso adotado por alguns voluntários, na caixa de rolamento, junto ao meio fio, é possível ver os quebra-molas e bueiros utilizados pelos voluntários para se orientarem.
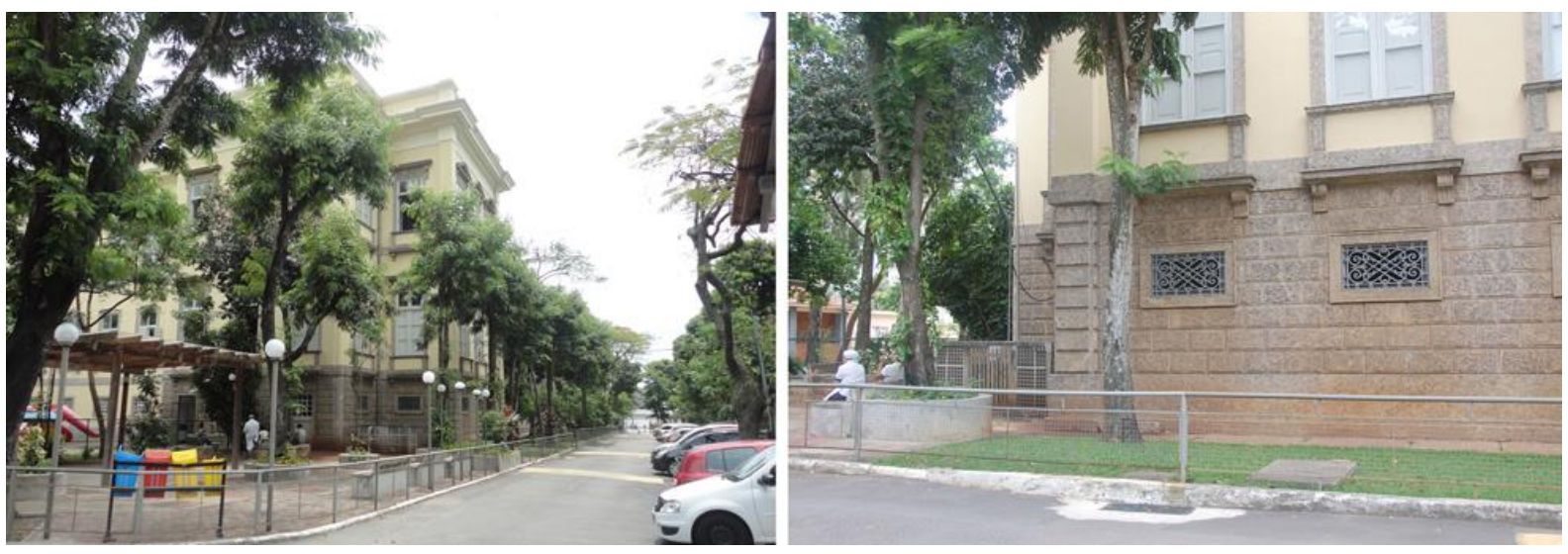

Fonte: O autor, 27/10/2015.

E o que julgamos como possibilidade de resposta para a questão apresentada acima diz que: Além da instalação de rampas, barras de apoio e elevadores (entre outros itens já balizados), devemos considerar a importância de proporcionar experiências sensoriais que transmitam informação, conforto, acolhimento, afetividade, sensações de integração e de pertencimento. Porque constatamos que a luta das pessoas com deficiência está em um processo evolutivo que transcende a barreira da aceitação de sua condição física ou psicológica pela sociedade e atinge um patamar de busca por uma crescente melhora da sua qualidade de vida e uma maior interação e troca de informações com outras pessoas.

Devemos então refletir sobre as dimensões do ambiente construído e do corpo, de modo a avaliar as formas de desenvolver o valor do patrimônio cultural e transformar edifícios em espaços de experiência e concretização do exercício de afetividade para cada usuário, possibilitando a construção de um exercício de cidadania tanto para quem projeta os ambientes, quanto para quem oferta esses ambientes e também para os usuários, sejam eles pessoas com ou sem deficiência.

Como cita Pinheiro (2010), temas envolvendo o corpo humano em suas capacidades intelectuais e sensoriais são recorrentes na teoria arquitetônica. A organização do corpo, tendo como conquista mais espetacular o surgimento de uma "matemática do olhar" que se baseia na perspectiva, foi central para o desenvolvimento do Humanismo. No entanto, após esta inserção, o discurso arquitetônico passou a lidar com um conceito estático de corpo, no qual as capacidades aludiam a uma busca por centralização dos objetos e não correspondem, nem de longe, às demandas científicas e estéticas das necessidades atuais do corpo (com deficiência, ou não) que usa a cidade e os edifícios como veículo de uma experiência.

A leitura contemporânea do espaço estruturado sugere uma noção de corpo que deve ser buscada sobre os diversos tipos possíveis: o corpo individual, o coletivo, o corporativo e institucional e o corpo que ainda busca seu espaço de uso, como é o caso do corpo das pessoas com deficiência visual, que muitas vezes ficam restritas ao uso de uma pequena parcela dos ambientes construídos devido à ausência de comunicação adequada entre o corpo da pessoa com deficiência e a edificação.

E como exercício prático, foi defendido nesse trabalho um conjunto de apontamentos de intervenções necessárias para melhorar a funcionalidade e conforto ambiental para os usuários do IBC (Figura 3). O projeto de intervenção apresentado aqui busca gerar maior proximidade e interação entre as pessoas e as superfícies do prédio histórico por meio de tratamento arquitetônico e paisagístico focados principalmente na acessibilidade e estímulos sensoriais aplicados às pessoas com deficiência visual (público alvo do IBC), mas vale atentar para o fato de que o projeto não é restrito a nenhum tipo de público e manteve o compromisso com a humanização da arquitetura muito inspirado nos conceitos difundidos por Alvar Aalto (1978, p.55) e Juhani Pallasmaa (2011, p. 67-68).

A proposta projetual buscou demonstrar formas possíveis para a construção de caminhos ladeados por elementos capazes de transmitir às pessoas conforto físico e psicológico, para que estes usuários, em especial as pessoas com deficiência visual, possam desfrutar de áreas do IBC ainda pouco exploradas por elas e assim, obter uma nova perspectiva para que percebam o ambiente a sua volta e o valor das edificações como patrimônio. 
Silva, A. F. G.

Figura 3: Mapa de fotos e localização das principais intervenções.

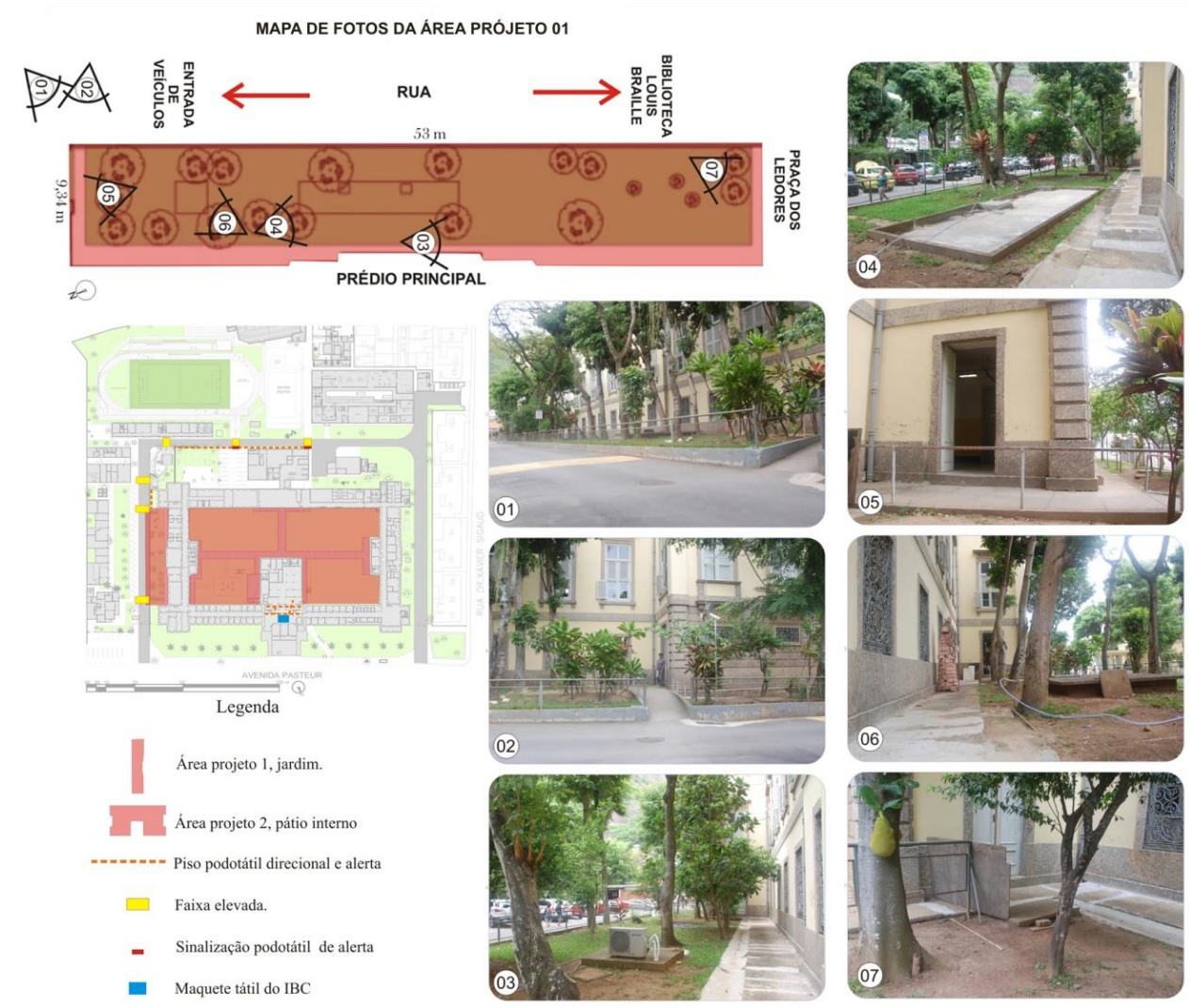

Fonte: O autor, 27/10/2015.

Figura 4: Perspectiva do projeto paisagístico composto de elementos em alvenaria e concreto, priorizando a construção de áreas de descanso, circulação e contemplação dos canteiros e jardineiras projetados que servirão para o plantio de jardins sensoriais.

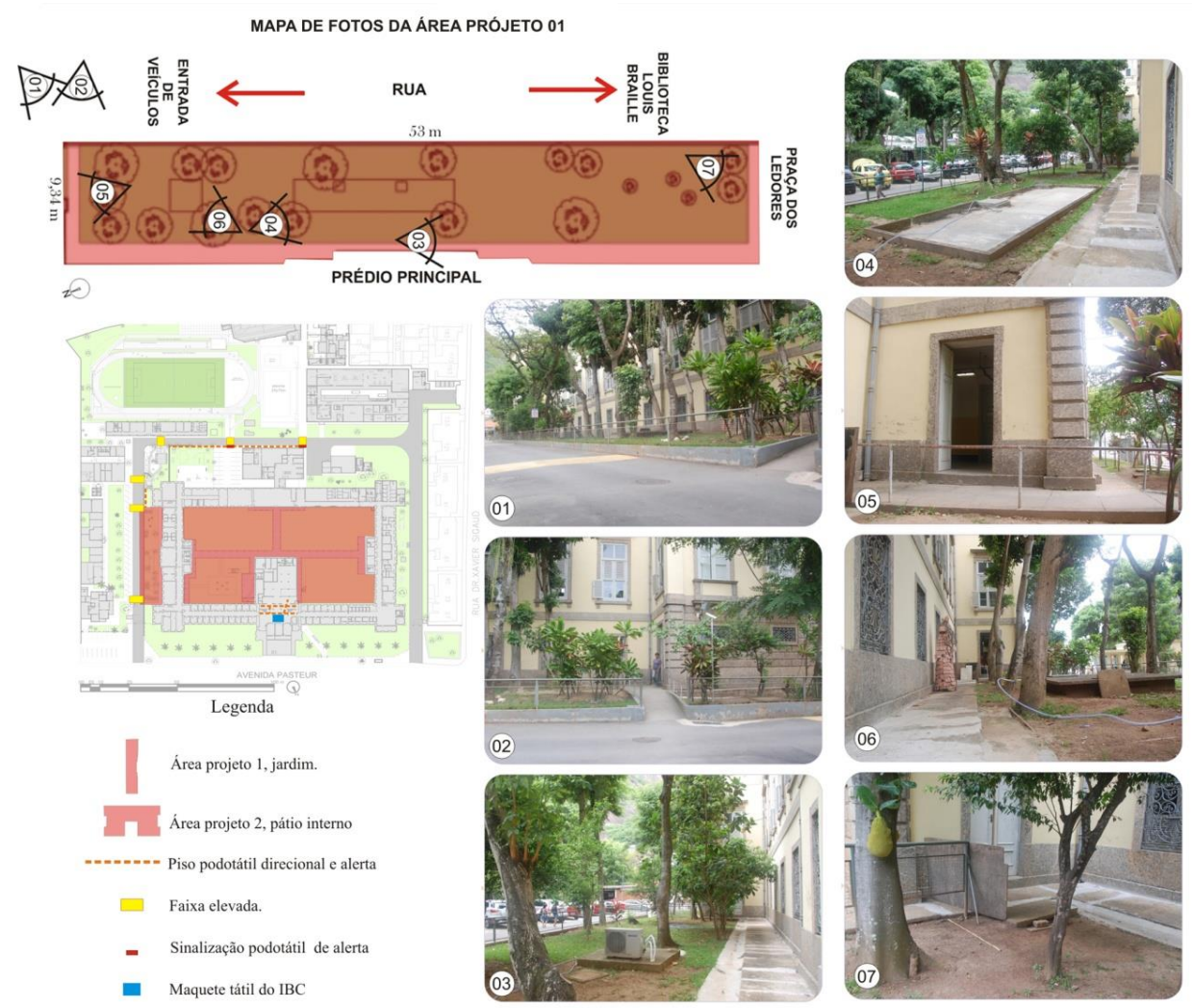

Fonte: O autor, 27/10/2015. 
Silva, A. F. G.

Figura 5: Perspectiva do projeto paisagístico composto de elementos em alvenaria e concreto, priorizando a construção de áreas de descanso, circulação e contemplação dos canteiros e jardineiras projetados que servirão para o plantio de jardins sensoriais.

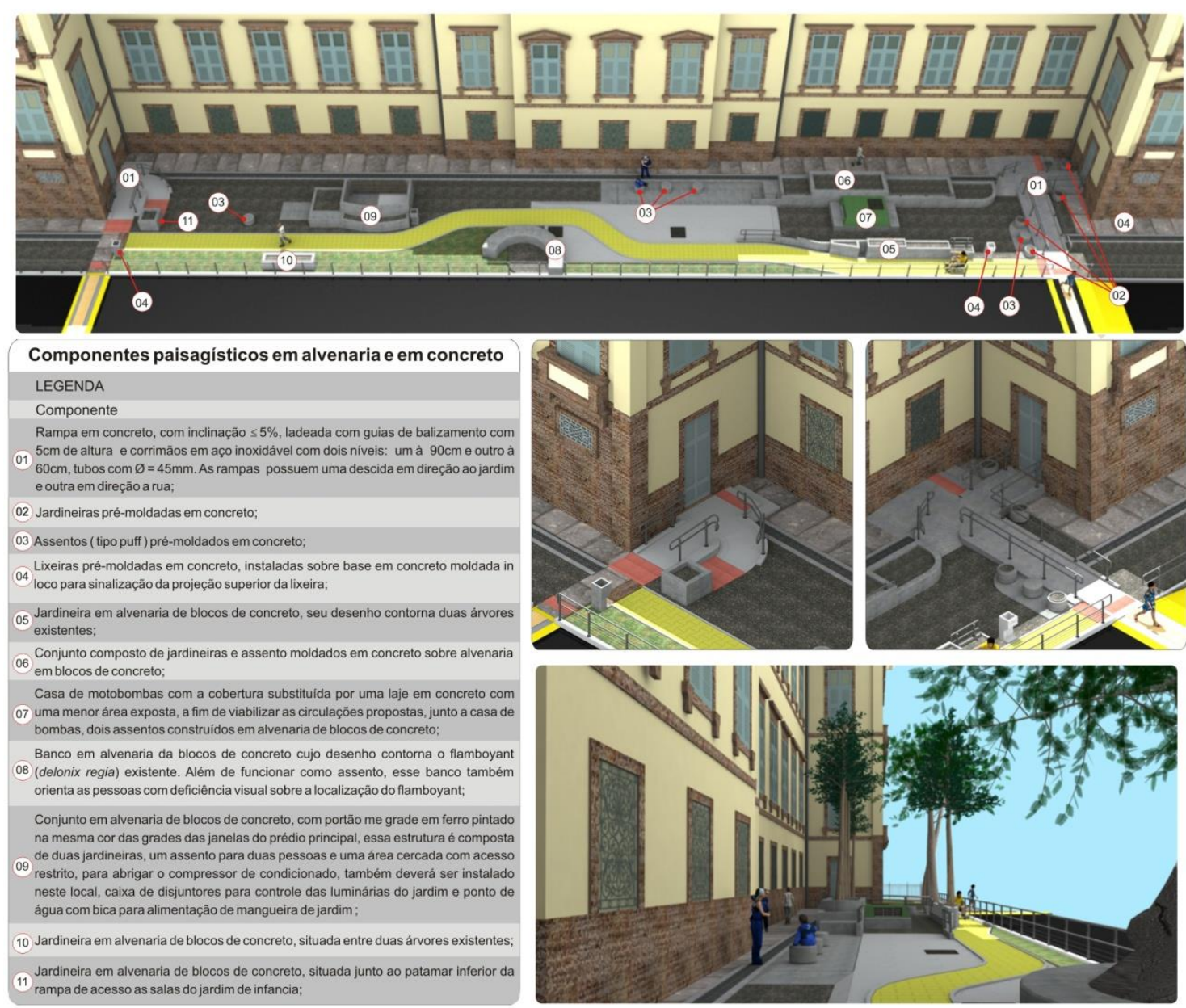

Fonte: O autor, 27/10/2015.

O material produzido por esta pesquisa pode contribuir também para atender às demandas de adaptação para o público com deficiência ou mobilidade reduzida em outros ambientes com valor histórico e cultual, demonstrando que as diretrizes apresentadas nas Normas são boas referências, mas um projeto de arquitetura inclusiva pode e deve alcançar possibilidades que vão além da instalação de pisos táteis, textos em braille, rampas, banheiros acessíveis e outros componentes previstos em Lei. Cada edificação possui sua peculiaridade e deverá ser estudada detalhadamente para que a inclusão seja implantada de forma plena, priorizando a humanização destes ambientes, a acessibilidade e a possibilidade de contemplar as sensações do lugar, e a evolução desse processo deverá ocorrer de acordo com o surgimento de novas tecnologias, e novos conceitos de percepção.

\section{REFERÊNCIAS}

AALTO, Alvar (1978). La humanización de la arquitectura. Barcelona: Tuquets. Serie de Arquitectura y Diseñ dirigida por Xavier Sust. Volumen 9.

PALLASMAA, Juhani. Os olhos da pele: a arquitetura e os sentidos. Tradução técnica: Alexandre Salvaterra. Porto Alegre: Bookman, 2011.

PINHEIRO, Ethel. Cidades 'Entre': Dimensões do sensível em arquitetura ou a Memória do Futuro na Construção de uma Cidade. Rio de Janeiro: PROARQ/FAU/UFRJ. Tese (Doutorado em Arquitetura), 2010.

SILVA, André Fernandes Gomes da. Além da Rota Acessível: projeto de acessibilidade aplicado à revitalização do Patrimônio consolidado do Instituto Benjamin Constant. 2015. 129 f. Dissertação (Mestrado Profissional em Projeto e Patrimônio) - PROARQ/UFRJ - Programa de Pós-graduação em Arquitetura da Universidade Federal do Rio de Janeiro, Rio de Janeiro, 2015.

THIBAUD, J. P. La Méthode des Parcours Commentés. In Grosjean, M.; Thibaud, J. P. (orgs), L'espace Urbain en Méthodes. Marseille: Ed. Parenthèses, 2001 p. 79-99. 
Instrução Normativa $1^{1}{ }^{\circ}$, de 25 de novembro de 2003. IPHAN, 2003.

Lei Federal $n^{0}$ 10.048/2000

Lei Federal no 10.098, de 19 de dezembro de 2000.

Decreto $n^{\circ} 5.296 / 2004$

ABNT. Acessibilidade a edificações, mobiliário, espaços e equipamentos urbanos. NBR 9050/2004.

Convenção sobre Direitos das Pessoas com Deficiência das Nações Unidas (CDPD), 2006.

NOTA DO EDITOR (*) O conteúdo do artigo e as imagens nele publicadas são de responsabilidade do(s) autor(es). 


\title{
GESTÃO EM OBRAS DE RESTAURAÇÃO NO PATRIMÔNIO EDIFICADO
}

\author{
ANTONIAZZI, THAIS HOFMEISTER \\ Arquiteta, MSc.; email: thais.hof@gmail.com \\ Dissertação desenvolvida no Mestrado Profissional em Projeto e Patrimônio, PROARQ/UFRJ - \\ Programa de Pós-graduação em Arquitetura da Universidade Federal do Rio de Janeiro. \\ Orientadora: Rosina Trevisan M. Ribeiro
}

\section{RESUMO EXPANDIDO}

Um dos maiores desafios ao se executar uma obra de intervenção em edificações de interesse de preservação está em lidar com a complexidade da multidisciplinaridade que envolve o processo, compreendendo tecnologia, história e arte.

No âmbito da construção civil convencional, a gestão de obras é um processo que abrange um amplo e diversificado conjunto de atividades técnicas e administrativas. Realizado por profissionais qualificados, através de ferramentas específicas, planeja, organiza e monitora, no sentido não só de atingir as metas, como de otimizar resultados (figura 1). No contexto das obras de restauração ${ }^{1}$ o processo de gestão demanda uma maior complexidade, visto que o objeto de intervenção é culturalmente um bem de reconhecido valor, o que requer, antes de tudo, cuidados especiais e atendimento a normas específicas.

Figura 1: Gestão - áreas de atuação.

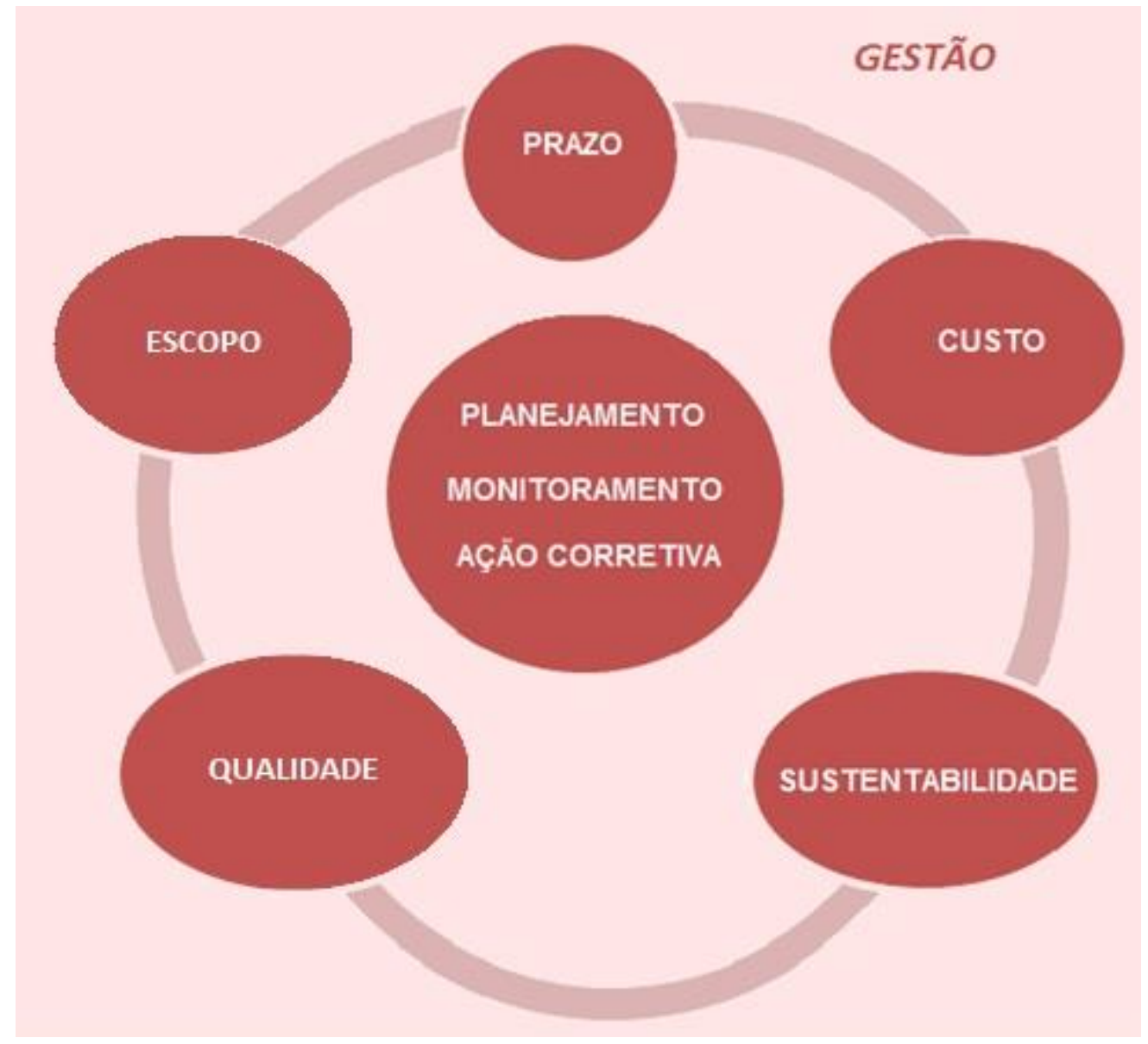

Fonte: A autora, 2015. 
Conforme a Carta de Veneza (1964), a conservação e a restauração dos monumentos visam "a salvaguardar tanto a obra de arte como o testemunho histórico [...], a restauração é uma operação que deve ter caráter excepcional. Tem por objetivo conservar e revelar os valores estéticos e históricos do monumento e fundamenta-se no respeito ao material original e aos documentos autênticos. Termina onde começa a hipótese; [...]".

Isto posto, torna-se notório que obras de restauração devem ser conduzidas de forma diferenciada a obras da construção civil convencional, sendo essencial a presença da atividade de gestão durante todo o processo, ou seja, do projeto à entrega da obra.

De maneira distinta dos empreendimentos tradicionais, os projetos e as obras de restauração possuem características particulares que refletem num padrão de processos diferente, do planejamento até a sua finalização. Diferenças estas com influências na produtividade, impacto nos custos e nos prazos. Deste modo "os resultados esperados precisam ser dimensionados levando-se em conta as características específicas e os riscos envolvidos nesse tipo de empreendimento" (CROITOR; MELHADO, 2009, p.7).

Dentre estas características particulares da restauração podemos ressaltar, entre outras, os materiais diferenciados, de época; técnicas construtivas antigas aplicadas e mão de obra especializada para todos os níveis profissionais. Também, muito importante é o papel da educação patrimonial, na conscientização da classe operária do valor e importância de seu trabalho, consequentemente, dos cuidados necessários na realização das tarefas.

Outros aspectos diferenciais que a serem ressaltados neste tipo de obra são os das proteções especiais e o canteiro de obras. Proteções de elementos arquitetônicos, artísticos, revestimentos, etc., são necessariamente realizadas, para que os mesmos não se danifiquem ao longo dos serviços. Já na área do canteiro de obras de restauro, o aspecto da segurança é bastante relevante não só por se tratar de área circunscrita a um monumento histórico, como também por ser lugar de manuseio e guarda de elementos da construção, com valor de patrimônio.

Ainda como fator diferencial significativo nas obras de restauração, cabe ressaltar a importância dos registros das intervenções, como por exemplo, as realizadas em elementos artísticos integrados (figura 2), que fará parte da documentação histórica do bem, como também da gestão no monitoramento pós-obra, no acompanhamento do comportamento das novas tecnologias aplicadas, responsabilidade técnica da empresa, e que contribuirá para o seu aprimoramento no desenvolvimento de novas técnicas de trabalho, na área do restauro.

Portanto, a gestão da obra deve deixar estabelecidos os procedimentos de manutenção pós-ocupação, pois as ações para a preservação do bem devem ser contínuas, e passam a ser de responsabilidade do usuário. Para isto, destaca-se a importância dos Manuais do Proprietário, como também da adoção por parte das empresas, de uma política de orientação prática para o período pós-ocupação.

Comumente as obras de restauração vêm associadas a obras civis para implantação de um novo uso, o que é desejável, principalmente aos bens sem uso, que se reintegram no contexto urbano de forma renovada e passam a ser de utilidade à sociedade.

O desenvolvimento do projeto de restauração tem como ponto de partida a articulação de três aspectos, que Ihe são peculiares: edificação existente; preservação do bem tombado; um programa de uso. Portanto este tipo de projeto não pode ser compreendido como ação que se refere apenas sobre as questões de restauração. Os projetos para a restauração do edifício e requalificação dos espaços devem ser desenvolvidos em conjunto e compatibilizados, respeitando o aspecto original do prédio; levando em consideração os preceitos e atendendo as normas e legislação específica de Preservação do Patrimônio Cultural, tal qual consta das premissas do Manual do IPHAN (GOMIDE; SILVA; BRAGA, 2005).

Segundo o referido Manual, para a elaboração de Projetos de Restauração é essencial que se conheça os documentos internacionais e os princípios enunciados nas cartas patrimoniais. O Manual descreve ainda que para a apresentação de Projeto Básico de restauração do patrimônio edificado, o processo deve ocorrer em três etapas: as duas primeiras, destinadas à identificação e conhecimento do bem, levantamento e diagnóstico; a terceira etapa, ao projeto de intervenção.

A lei 8.666/93 permite a realização de uma licitação de obra baseada somente no projeto básico, podendo o projeto executivo ser desenvolvido paralelamente ao início da obra. Com isto as informações de edital acabam por ficarem incompletas provenientes de um projeto sem detalhamentos e compatibilizações, gerando orçamentos irreais, levando comumente a valores significativos de aditivos contratuais, ou ao contrário: em função da incerteza e dos riscos, orçamentos supervalorizados e desperdícios de verba pública. 
De acordo com o art. $3^{\circ}$ da Lei $8666 / 3$, as licitações devem garantir a igualdade de condições a todos os licitantes. Para tanto, para avaliações comparativas entre propostas, não apenas em relação ao preço, mas, principalmente, em sua capacidade técnica, as informações contidas nos instrumentos de convocação das licitações devem oferecer todas as informações necessárias para a licitação com relação a escopo, materiais, custo e tempo. Dessa forma, conclui-se que reais condições de igualdade entre licitantes só serão alcançadas com sucesso, por meio do projeto executivo, o que trará a situação de isonomia aos licitantes.

$\mathrm{Na}$ aplicação dos conhecimentos de gestão às particularidades das obras de restauro, verificou-se que a otimização dos resultados da obra está diretamente vinculada, entre outros, à qualidade do projeto, já que a causa de grande parte dos problemas das obras de restauração não é pertencente à execução da obra propriamente dita, pois acontecem nas etapas de diagnóstico e de projeto e acabam por refletir nas ações pertinentes à fase da obra.

É fato que o elemento surpresa é um aspecto inerente a este tipo de empreendimento. O surgimento, durante a execução das obras de restauração, de elementos desconhecidos na época da elaboração dos projetos, leva à impossibilidade de se garantir um escopo totalmente definido no ato da contratação, trazendo por consequência, aditivos de custo e de prazo. Tais questões se agravam frequentemente por ocorrem também pela ausência de diagnósticos mais completos e, ou, de projetos mais detalhados na fase da licitação, problemas estes pertinentes a etapas anteriores a obra, advindos de brechas na legislação e da política das contratações públicas, que possibilitam tais situações.

Por tudo isto, entende-se necessária a revisão legislativa, uma ação importante a ser perseguida pelos órgãos públicos, pois viria a eliminar uma parte significativa de fatores geradores de problemas tão comuns, que ocorrem na fase de execução das obras. Com este objetivo, e ainda que externo ao âmbito da gestão de obra especificamente, este trabalho apresenta como diretrizes básicas, algumas proposições de ações consideradas necessárias, para a alteração da atual política de contratações das obras de restauração, no que se refere ao projeto de restauração e capacitação de profissionais.

Sugere-se, na esfera de atuação da fiscalização pública, a criação pelos órgãos de tutela, de um Grupo de Trabalho responsável pela elaboração de um Manual Básico de Gestão de Fiscalização de Obras Públicas de Restauração. Deste manual, a parte que caberá a responsabilidade da execução dos procedimentos pela empresa contratada poderá vir a integrar o Edital, garantindo assim uma linha básica comum de atuação e a implementação da prática de procedimentos administrativos, técnicos e de gestão desejados pela gestão pública.

Sugere-se, ainda, a criação de um Grupo Nacional Integrado de Trabalho, constituído por profissionais representantes de cada órgão de tutela do país e responsável pela criação de um banco nacional de dados, para serviços de restauração. Isto possibilitaria a troca de informações de forma ágil, a divulgação das novas experiências, das lições aprendidas, enriquecendo o universo deste conhecimento, e, quem sabe, vindo a fomentar discussões e debates, tão carentes em nosso país, acerca da atuação e dos critérios nacionais de intervenção praticados no patrimônio edificado.

Diante do exposto, para as obras de restauração propõe-se ainda:

Estabelecer como pré-requisito para a licitação de obras de restauração, que os projetos de restauração e complementares de arquitetura e engenharia, sejam obrigatoriamente em nível de Projeto Executivo; que o arquiteto responsável pelo projeto de arquitetura tenha formação complementar reconhecida pelo Ministério de Educação, na área específica de Patrimônio.

A utilização do edital como ferramenta de atuação bastante acessível e imediata, na garantia de condições para as contratações de serviços de restauração, podendo neste instrumento serem previstos:

- A contratação das obras de restauração por preço unitário, nos casos em que os objetos por sua natureza, possuam uma imprecisão inerente de quantitativos em seus itens orçamentários;

- Ações de Educação Patrimonial de forma a contribuir com a formação de profissionais da área, do operariado a profissionais técnicos em geral, bem como treinamento das equipes de manutenção e limpeza, pela empresa executora da obra, para os serviços correlacionados a elementos artísticos ou construtivos de época;

- Elaboração de relatórios técnicos específicos para os serviços realizados com novas tecnologias de aplicação, contendo descrição dos procedimentos técnicos executados, ficha técnica dos materiais utilizados bem como a composição de custos. Elaboração também das especificações e Plano de Monitoramento destes serviços e materiais, bem como da metodologia de registro do monitoramento;

- Em caso de indicação da necessidade da realização de Pesquisa Arqueológica, a obrigatoriedade de apresentação de um Plano de Ação e Diretrizes para a realização da Pesquisa Arqueológica; cronograma de execução devidamente elaborado por arqueólogo responsável, compatibilizadas com o cronograma geral da obra. 
A implementação de tais diretrizes traria melhores condições para a realização dos projetos, gerenciamento e realização das obras de restauração propiciando assim a obtenção de resultados mais eficazes na salvaguarda do patrimônio a ser transmitido a gerações futuras, como também a obtenção de melhores resultados para a administração pública.

Além da implementação das boas práticas de gestão é necessária uma mudança significativa na política de atuação da gestão pública, caso contrário, continuarão sendo soluções paliativas, os esforços na busca de melhoria contínua dos processos de gestão das obras de restauração, na contribuição da preservação sustentável do bem cultural.

O amplo universo da gestão e da restauração pressupõe ação constante de desenvolvimento e atualização, na elaboração de adaptações e na criação de procedimentos e instrumentos de gestão para as especificidades do restauro, numa vasta gama de abrangência de abordagem, entre temas técnicos e administrativos. Este trabalho é uma sugestão inicial, a ser complementado ao longo do tempo, na continuidade do desenvolvimento dos procedimentos ou de suas atualizações, a serem divulgados para difusão dos novos conhecimentos e aplicação, no sentido de colaborar para uma preservação mais sustentável do patrimônio edificado.

Figura 2: Ficha de Registro de Intervenção em Elemento Artístico Integrado.

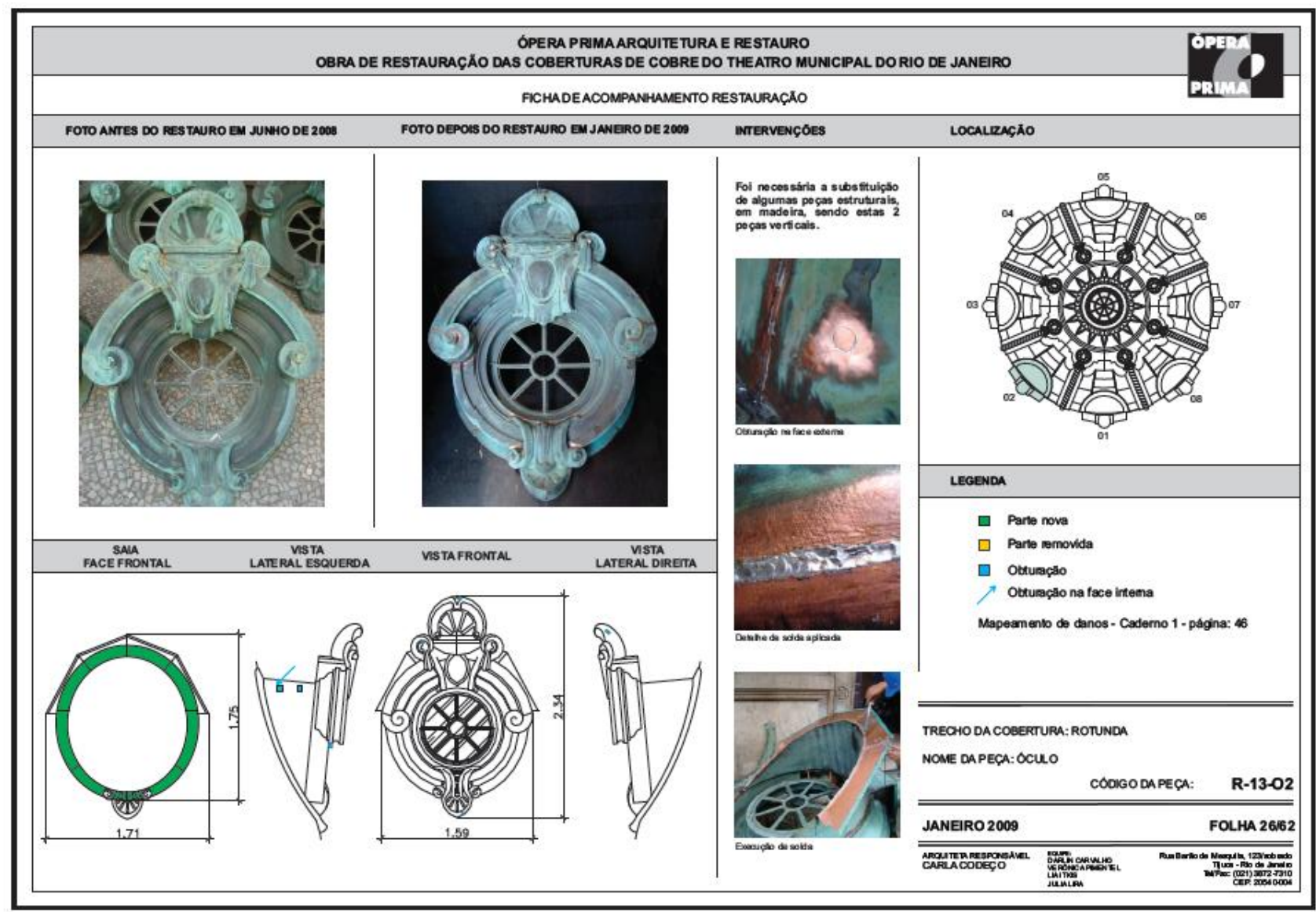

Fonte: Empresa Ópera Prima, 2015.

\section{REFERÊNCIAS}

ANTONIAZZI, Thais Hofmeister. Gestão em Obras de Restauração no Patrimônio Edificado. 2015. Dissertação (Mestrado Profissional em Projeto e Patrimônio) - PROARQ/UFRJ - Programa de Pós-graduação em Arquitetura da Universidade Federal do Rio de Janeiro, Rio de Janeiro, 2015.

BRASIL. Lei $n^{\circ}$ 8.666, de 21 de junho de 1993. Regulamenta o art. 37, inciso XXI, da Constituição Federal, institui normas para licitações e contratos da Administração Pública e dá outras providências. Disponível em: http://www.planalto.gov.br/ccivil_03/leis/L8666compilado.htm. Acesso em: 26 fev2015.

GOMIDE, José Hailon; SILVA, Patrícia Reis da; BRAGA, Sylvia Maria Nelo. Manual de elaboração de projetos de preservação do patrimônio cultural. Brasília: Ministério da Cultura, Instituto do Programa Monumenta, 2005. 
CARTA DE VENEZA, 1964. Carta Internacional sobre Conservação e Restauração de Monumentos e Sítios. II Congresso Internacional de Arquitetos e Técnicos dos Monumentos Históricos. Veneza, maio de 1964. Disponível em: http://portal.iphan.gov.br/portal/baixaFcdAnexo.do?id=236. Acessado em 08/01/15. Acesso em: 10 fev.2015.

CROITOR, E. P. N., MELHADO, S. B.. A gestão de projetos aplicada à reabilitação de edifícios: estudo da interface entre projeto e obra. Boletim Técnico: BT/PCC/529, São Paulo, v., n., p.1-26, 2009. Disponível Em: http://publicacoes.pcc.usp.br/PDF2009/BT529.pdf. Acesso em: 16 dez.2014.

KÜHL, Beatriz Mugayar. História e Ética na Conservação e na Restauração de Monumentos Históricos. Revista. CPC, São Paulo, v.1, n.1, p. 16-40, abr. 2006. Disponível em:

http://novoportal.iphan.gov.br/uploads/ckfinder/arquivos/Anexo,\%20texto\%203.pdf. Acesso em: 07 fev.2015.

\section{NOTAS}

1 Neste trabalho, ao referir a "obras de restauração" ou "obra de restauro", trata-se de obras em edificações de interesse de preservação que possuem critérios e métodos específicos de atuação, próprios do patrimônio cultural edificado, incluindo a reabilitação do edifício.

NOTA DO EDITOR (*) O conteúdo do artigo e as imagens nele publicadas são de responsabilidade do(s) autor(es). 


\title{
INSTRUMENTOS E TÉCNICAS PARA SISTEMA DE IDENTIFICAÇÃO E REGISTRO DE VITRAIS
}

\author{
VIANA, HELDER MAGALHÃES \\ Arquiteto, MSc.; Instituto Rio Patrimônio da Humanidade, email: helder.restauro@gmail.com \\ Dissertação desenvolvida no Mestrado Profissional em Projeto e Patrimônio, PROARQ/UFRJ - \\ Programa de Pós-graduação em Arquitetura da Universidade Federal do Rio de Janeiro. \\ Orientadora: Claudia Carvalho Leme Nóbrega
}

\section{RESUMO EXPANDIDO}

A longevidade de um vitral é inversamente proporcional à natureza frágil de seus materiais. Embora existam exemplares conservados que remontam a um período de cerca de mil anos, foram várias as perdas causadas pela falta de conhecimento do valor de muitas destas obras. Considerando que o conhecimento é o primeiro passo na busca de uma proteção efetiva dos bens culturais, este trabalho teve como objetivo principal a elaboração de uma ferramenta específica para a identificação e o registro de vitrais.

Esta pesquisa surgiu a partir da observação de inúmeros exemplares de vitrais existentes na Cidade do Rio de Janeiro, na sua maioria, integrados a edificações protegidas por órgãos de proteção do patrimônio cultural, porém, sem um registro de identificação adequado às necessidades de proteção.

Muitas vezes os bens móveis e integrados são responsáveis por agregar valores que transformam o imóvel em um bem de interesse cultural. A ausência de registros adequados destas categorias de bens nas edificações protegidas revela uma lacuna que precisa ser preenchida. Sendo parte integrante desta realidade, os poucos registros existentes sobre vitrais não contemplam uma das principais particularidades deste elemento referente às possíveis relações entre outros objetos e a própria edificação onde está inserido.

Para se chegar a um modelo que atendesse às necessidades específicas deste elemento, o trabalho tem início pela conceituação e delimitação do objeto de estudo e por uma pesquisa sobre a história do vitral no Rio de Janeiro, sobre exemplos existentes e sobre profissionais e fornecedores que atuaram nesta cidade, comprovando assim a relevância de seu acervo. Apresenta também experiências de inventários na Europa e de registros de vitrais no Brasil, como base para a elaboração de uma ficha de inventário e de um roteiro de preenchimento. A partir da identificação das particularidades do vitral e das diversas relações deste objeto com o espaço onde está inserido e com outros bens, apresenta como produto final uma ficha de identificação e registro de vitrais aplicada a uma janela da Basílica Imaculada Conceição, bem tombado localizado no bairro de Botafogo, no Rio de Janeiro.

\section{Conceituação}

Considerando o vidro como o principal e essencial elemento na composição de um vitral, é proposta a seguinte definição:

O vitral é um tipo de vidraça, portanto um objeto, frequentemente integrado à arquitetura, composto de pedaços de vidro reunidos conforme diferentes técnicas, formando uma composição artística ou decorativa.

A partir desta definição, além dos variados vitrais sacros e profanos executados com a tradicional técnica de vidro e chumbo, é possível incluir importantes obras existentes na Cidade do Rio de Janeiro, como os vitrais do Edifício Central da Caixa Econômica Federal (1969) e os da Catedral Metropolitana de São Sebastião (1976) (Figura 1), ambos em vitrais executados em vidro e cimento, produzidos pelo artista plástico, vitralista e vidreiro Lorenz Heilmair. 
Viana, H. M.

Figura 1: Detalhe do vitral leste da Catedral Metropolitana do Rio de Janeiro e assinatura localizada no vitral oeste.

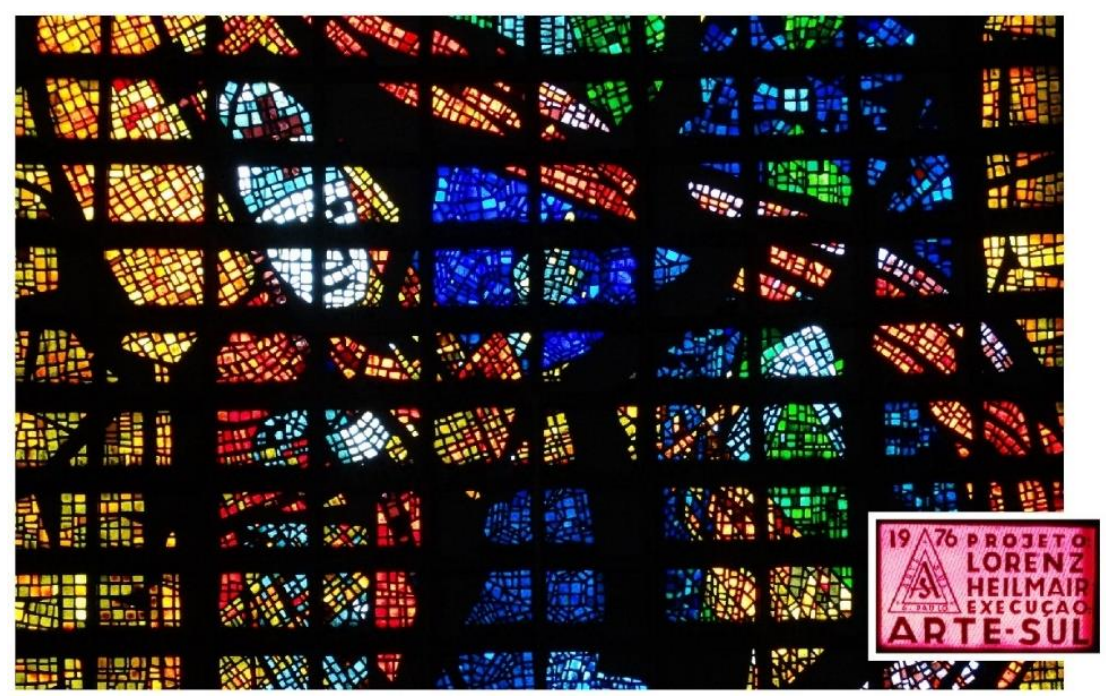

Fonte: Foto do autor.

\section{Inventários de vitrais}

O pioneirismo europeu no registro de vitrais foi motivado pelas perdas causadas por muitas guerras que assolaram aquele continente, mas também pelo fato da convivência com eles há pelo menos mil anos, o que faz dessas perdas algo que atinge mais profundamente uma sociedade que valoriza suas tradições. $O$ princípio adotado pelo Corpus Vitrearum, uma instituição acadêmica internacional, foi o de registrar, mas também o de divulgar para o mundo através de suas publicações, exposições e conferências, a importância histórica e a valorização artística dos vitrais medievais. Na França, esta campanha se multiplica com a iniciativa do governo de inventariar todo o seu patrimônio cultural a partir de 1964. Com a valorização, surgem também iniciativas independentes que buscam através do resgate e reunião das informações, valorizar a tradição do ofício e a memória de seus antepassados.

No Brasil, a perda do patrimônio edificado não passa pelo trauma da destruição das guerras, mas sim por uma constante transformação motivada principalmente pela especulação imobiliária, intensificada a partir da segunda metade do século XX. Diferente do que ocorrera na Europa, onde a proteção dos vitrais históricos nascera a partir da iniciativa da sociedade civil organizada, as iniciativas de proteção de bens culturais brasileiros foram promovidas por instituições governamentais. Os inventários de bens móveis e integrados em nosso país iniciados na década de 1980, foram e continuam sendo, importantes, porém, não abordam aspectos específicos sobre o vitral. Iniciativas individuais, mesmo isoladas, representam um importante ponto de partida para o conhecimento desse objeto, porém, para um efetivo conhecimento e valorização dos vitrais são necessárias a divulgação e a continuidade das pesquisas, revelando o conhecimento e despertando um maior interesse sobre esse patrimônio.

\section{Sistema de identificação e registro de vitrais}

Os inventários de bens do patrimônio cultural são sistemas de registros, de um modo geral, organizados em fichas cadastrais. Estes formulários devem contemplar as informações necessárias para melhor identificação e conhecimento do bem que se pretende registrar, neste caso objetivando sua valorização e proteção.

Para atender as particularidades específicas dos vitrais é necessário levar em consideração as diversas relações que podem existir entre o objeto cadastrado e outros objetos, além do imóvel em que este está inserido, visando ampliar as possibilidades de conhecimento para a valorização e para o auxilio a eventuais intervenções. Desta forma a ficha proposta se diferencia das fichas de inventários usuais utilizadas atualmente pelos órgãos de proteção do patrimônio cultural brasileiro, que possuem um caráter museológico de identificação isolada do objeto.

Para auxiliar a localização de um vitral em uma edificação, assim como a identificação de módulos de uma composição, é necessário utilizar um sistema de numeração que preferencialmente tenha um diálogo com formatos já adotados internacionalmente, facilitando possíveis intercâmbios de informações. $O$ trabalho apresentado utilizou como base o padrão de numeração de vitrais descrito no "Manuel de conservation, restauration et création de vitraux"” (Manual de conservação, restauração e criação de vitrais). 
A ficha proposta está dividida em quatro partes principais. Na primeira parte estão os campos relacionados à identificação, localização, proteção e estatuto jurídico. Compõe um grupo de informações cujo preenchimento é simplificado, porém, requerendo do técnico um olhar cuidadoso, equipamentos que registrem adequadamente as imagens e a localização georreferenciada, e o contato com os responsáveis pelo local do bem estudado.

A segunda parte da ficha abrange os campos relacionados às informações históricas e às informações do conjunto, caso a edificação ou o acervo museológico apresentem outros vitrais. Requer do técnico uma experiência maior em pesquisa e algum conhecimento sobre iconografia da história da arte. Nestes setores, alguns campos já necessitam das fontes das informações pesquisadas. É nesta parte que este trabalho se diferencia de outras fichas de inventário, pois possibilita a inserção de informações que visam um conhecimento sobre as relações que podem existir entre o vitral pesquisado e outros bens.

O setor analítico compõe a terceira parte da ficha. Com exceção dos dois primeiros campos (croqui e vista externa), os demais campos descritivos requerem um preenchimento especializado, exigindo, tanto quanto possível, a contribuição multidisciplinar. Desta forma, por exemplo, o campo "CARACTERÍSTICAS TÉCNICAS" requer o conhecimento sobre pintura em vidro, confecção de vitrais, serralheria e sistemas construtivos, necessitando a cooperação de um mestre vitralista e um arquiteto com experiência; o campo "CARACTERÍSTICAS ESTILÍSTICAS", um especialista em história da arte; o campo "CARACTERÍSTICAS ICONOGRÁFICAS / ORNAMENTAIS", um especialista em iconografia e iconologia; e finalmente o campo "análise do estado de conservação", que necessita de um especialista em conservação, de preferência com experiência em vitrais (Figura 2). As informações destes campos contribuem para o conhecimento mais detalhado do vitral estudado, assim como para sua valoração.

A última parte da ficha é destinada aos dados complementares. Possui campos para a documentação fotográfica, informações complementares dos demais campos, referências bibliográficas e para a identificação dos responsáveis pelo registro. A Figura 3 apresenta a primeira página da ficha de inventário proposta.

Figura 2: Estado de conservação do vitral da nave lateral da Igreja Bom Pastor, de autoria de Mayer de Munich.

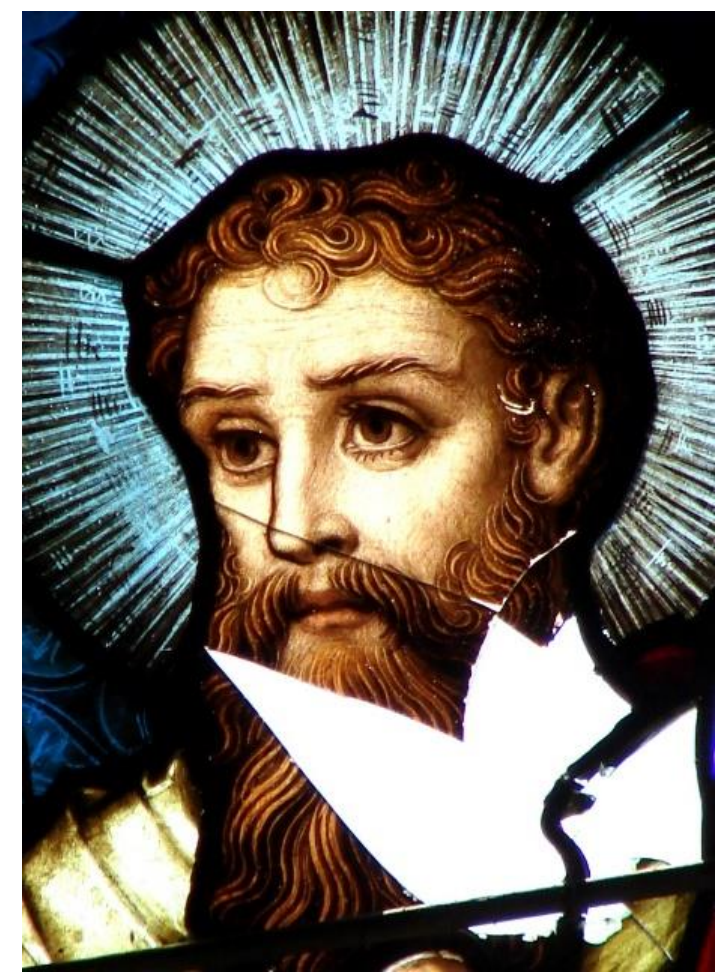

Fonte: Foto do autor.

\section{Considerações finais}

A proposta para a identificação e o registro de vitrais se inspira no lema do IPAC/MG, que diz: - "Para proteger temos que conhecer, para conhecer temos que inventariar", e adota parâmetros específicos para a melhor compreensão do objeto estudado. 
Ao disponibilizar a Ficha de Identificação e Registro de Vitrais e o roteiro para o seu preenchimento, o trabalho alcança o seu objetivo, contribuindo para o início de um processo que espera ser contínuo.

Os desdobramentos esperados a partir da disponibilização da ficha de identificação e registro de vitrais são:

- O fomento à execução de inventários específicos de vitrais nos órgãos de gestão e proteção do patrimônio cultural, ou qualquer outra instituição ou pessoa física que tenha como objetivo(s) o conhecimento, o registro e/ou a proteção de vitrais;

- O estimulo à criação de um banco de dados específico para vitrais;

- O fornecimento de subsídios para valorização, conservação e restauro de vitrais;

- A promoção de um debate para elaboração de uma portaria que normatize os critérios de cadastramento e registro para vitrais localizados em edificações que tenham algum grau de proteção.

Figura 3 - Aspecto da primeira página da ficha de identificação e registro de vitrais.

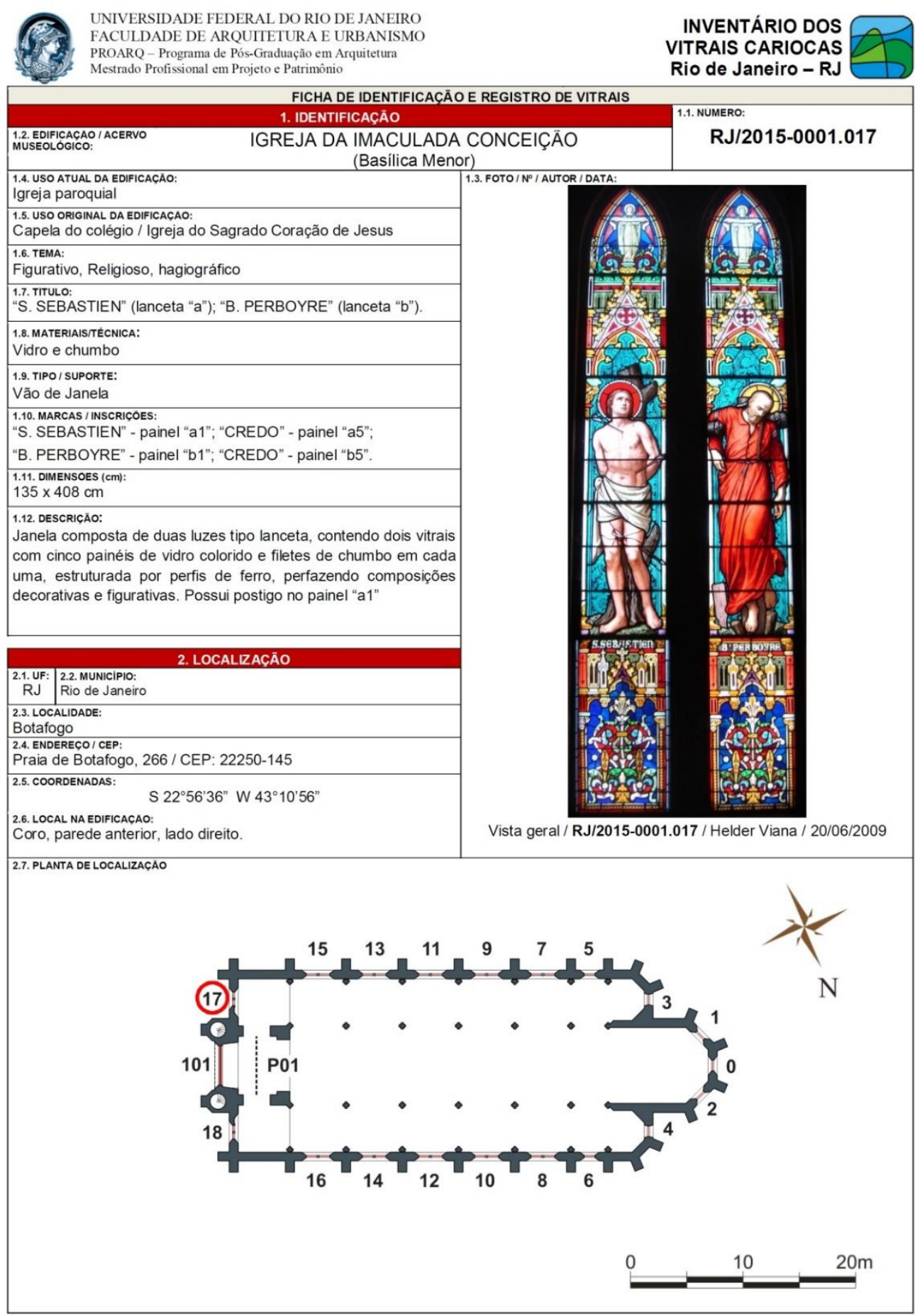

Fonte: Elaborada pelo autor 


\section{REFERÊNCIAS}

VIANA, Helder Magalhães. Instrumentos e técnicas para sistema de identificação e registro de vitrais. 2015. Dissertação (Mestrado Profissional em Projeto e Patrimônio) - PROARQ/UFRJ - Programa de Pós-graduação em Arquitetura da Universidade Federal do Rio de Janeiro, Rio de Janeiro, 2015.

\section{NOTAS}

${ }^{1}$ O Manual de conservação, restauração e criação de vitrais, integra uma série de manuais feitos para orientar os trabalhos de restauração de monumentos históricos franceses. É editado pela direção de arquitetura e do patrimônio do Ministério da Cultura e da Comunicação do governo da França. 


\title{
PLANO DE PRESERVAÇÃO DO CENTRO HISTÓRICO DE ANGRA DOS REIS/RJ E SUA APLICACÃO NA RUA DO COMÉRCIO
}

\author{
AZEVEDO, RAFAEL NASCIMENTO DE \\ Arquiteto, MsC., Professor CEULM/ULBRA Manaus; e-mail: rafael.arqt@gmail.com \\ Dissertação desenvolvida no Mestrado Profissional em Projeto e Patrimônio PROARQ/UFRJ - \\ Programa de Pós-graduação em Arquitetura da Universidade Federal do Rio de Janeiro. \\ Orientadora: Fabiola do Valle Zonno; Coorientadora: Rosina Trevisan M. Ribeiro
}

\section{RESUMO EXPANDIDO}

Inserida no debate sobre a valorização dos sítios históricos urbanos, a Dissertação intitulada "Plano de Preservação do Centro Histórico de Angra dos Reis e sua aplicação na Rua do Comércio", traz como objeto o principal núcleo urbano de um dos municípios mais antigos do território brasileiro com registros de fundação no século XVI, área com mais de 400 anos de ocupação, que apesar do processo de descaracterização de seu conjunto edificado de valor cultural iniciado a partir da segunda metade do século $\mathrm{XX}$, ainda conserva nas relações entre suas ruas, praças e o próprio conjunto edificado - sua forma urbana uma importante parcela do patrimônio cultural urbano do município que deve ser protegida contra as ações nocivas à sua conservação. Trata-se de uma verdadeira síntese da difícil associação entre a preservação dos valores culturais presentes em áreas urbanas, mesmo que bastante descaracterizados, e o planejamento urbano das cidades.

A definição do recorte (Figura 1) para aplicação da metodologia proposta, sendo definida a área compreendida pela Rua do Comércio e praças adjacentes (Praça General Osório, Praça Codrato de Vilhena e Praça Silvestre Travassos), se justifica pela representatividade desta via para o município como um todo, sendo uma das mais antigas de todo o município, suporte de importantes manifestações culturais como as festas religiosas e o carnaval de rua, além de concentrar um grande número de bens de valor cultural, identificados através de tombamentos, leis e estudos de preservação.

Figura 1: Mapa contendo os limites do Centro Histórico de Angra dos Reis e a localização do recorte em vermelho (à esquerda); e mapa do recorte: Rua do Comércio e Praças adjacentes (a direita).
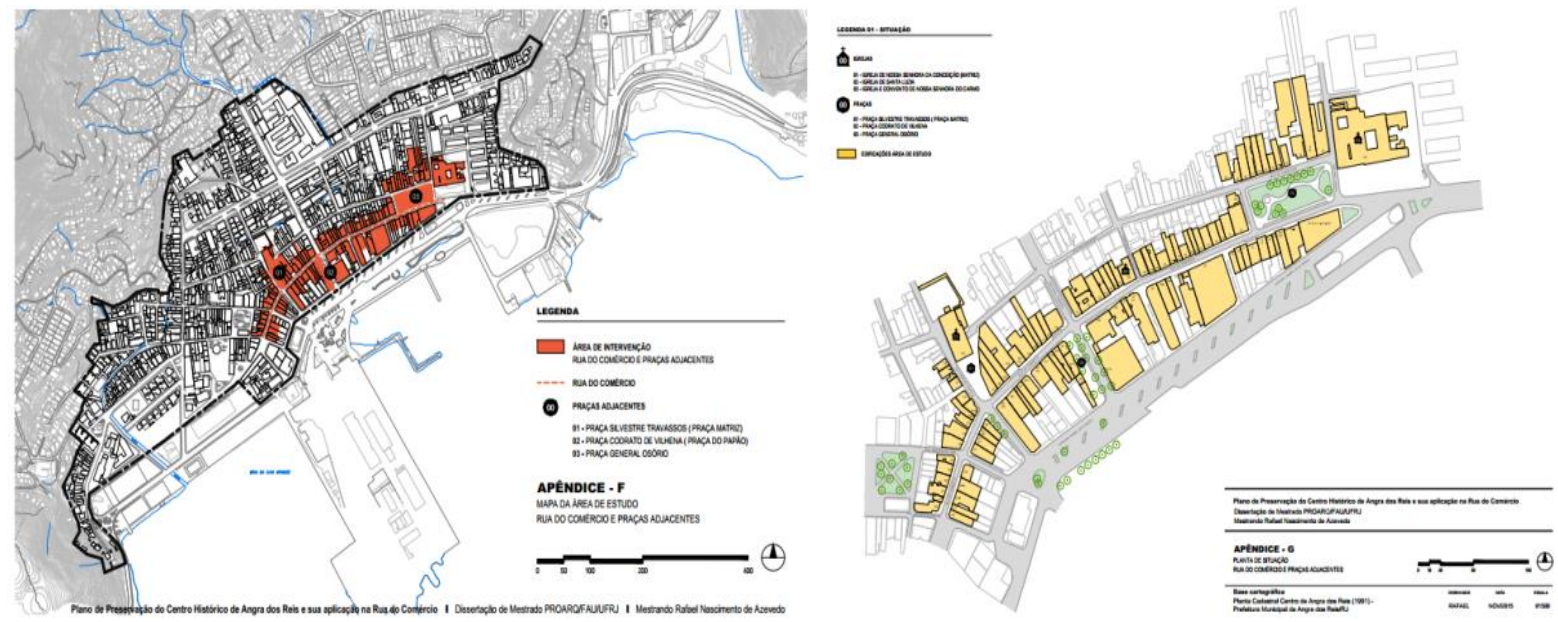

Fonte: O autor, 2015.

O principal objetivo deste trabalho é apresentar uma metodologia para elaboração de um Plano de Preservação para o Centro Histórico de Angra dos Reis, tendo como limites territoriais a ZECHAR (Zona Especial do Centro Histórico de Angra dos Reis), demonstrando sua viabilidade ao aplicá-lo sobre uma área constituída pela Rua do Comércio e praças adjacentes, apresentando ações para identificação e preservação do patrimônio cultural urbano ali presente. Tal proposta justifica-se pela necessidade de elaboração de estratégias e ações que garantam a preservação e a valorização do patrimônio cultural 
urbano do Centro Histórico de Angra dos Reis diante de um processo de descaracterização de seu conjunto edificado que vem ocorrendo desde a década de 1950, evitando assim a perda de importantes bens de valor cultural, além dos valores de ambiência presentes em seu conjunto (áreas livres e edificadas) através de ações mal orientadas.

Além das belezas naturais conhecidas mundialmente, Angra dos Reis/RJ também se destaca na história do país, sendo palco dos principais ciclos econômicos como o período de extração do ouro, o cultivo da canade-açúcar e café, sendo uma das principais áreas de escoamento desses produtos através de seu porto. A estrutura urbana de seu Centro Histórico tem início a partir do século XVII com a construção das edificações religiosas tais como o Convento de Nossa Senhora do Carmo (1593), Igreja de Santa Luzia (1632) e a Igreja Matriz de Nossa Senhora da Conceição (1750), seguida pela abertura das primeiras vias paralelas a orla marítima como destaque para a Rua Direita, atual Rua do Comércio. Com relação ao conjunto edificado (Figura 2), as riquezas provenientes da economia cafeeira trouxeram importantes transformações a partir do século XIX. A Rua Direita que abrigava edificações térreas com características da arquitetura civil do período colonial passou a ter fachadas com grande trabalho de ornamentação, representando o poderio econômico de seus proprietários, além da elevação de gabarito criando diversos sobrados. Neste período também são iniciadas as obras de aterro na orla marítima (ALVES FILHO, 2004).

Figura 2: Edificações da Rua do Comércio.

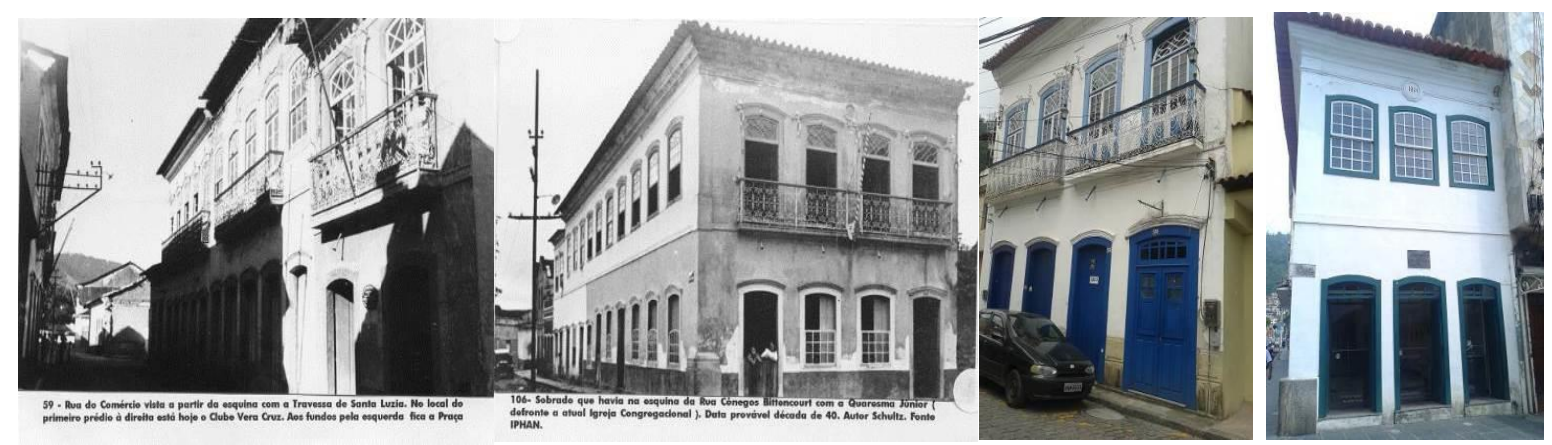

Fonte: Prefeitura Municipal de Angra dos Reis, fotos do autor, 2015.

Até a segunda metade do século XX a paisagem urbana de Angra dos Reis era composta por edificações das mais diversas linguagens históricas como exemplares de arquitetura colonial, eclética e Art Déco com tipologias variadas, formando um conjunto edificado de caráter heterogêneo, mas de grande harmonia. Este cenário passa por transformações a partir da construção de grandes empreendimentos industriais como o Estaleiro Verolme (1959), as Usinas Nucleares Angra I e Angra II (1972) e a abertura da Rodovia BR-101 (1974), gerando um crescimento populacional com reflexo direto sobre a paisagem urbana do Centro Histórico que teve as áreas de morros de seu entorno completamente ocupadas.

A partir da década de 1950, estudos do IPHAN - Instituto do Patrimônio Histórico e Artístico Nacional visando o tombamento do Conjunto Arquitetônico de Paraty (1958), também impactaram a paisagem urbana do Centro Histórico de Angra. As ações preservacionistas no município vizinho foram encaradas pela elite dominante como uma ameaça ao progresso de Angra dos Reis, fazendo com que incentivassem, com o apoio do poder público municipal, um processo de descaracterização do conjunto edificado do Centro Histórico para que fossem erguidas novas edificações, gerando assim perdas de conjuntos arquitetônicos e exemplares de grande valor artístico. Os bens protegidos desse verdadeiro processo de destruição foram as edificações e monumentos tombados pelo IPHAN, pelo Estado após estudos do Instituto Estadual do Patrimônio Cultural (INEPAC), além dos bens preservados pelo Decreto Municipal 431/93, até sua revogação em 2008, marco importante para o início desta Dissertação.

Com a revogação do citado Decreto que protegia mais de 100 imóveis do Centro Histórico e a criação de instrumentos normativos de baixa eficiência em virtude de falhas técnicas presentes em seus textos, criouse um cenário de "desproteção" que vem permitindo a descaracterização de diversas edificações de valor cultural, num processo contínuo que estabelece um prognóstico de grandes perdas em curto prazo.

A elaboração do trabalho teve início com uma revisão teórica-conceitual correlata ao debate sobre a preservação de sítios históricos urbanos, abordando temas como definições contemporâneas sobre patrimônio cultural e centros históricos, além dos debates nacionais e internacionais através das contribuições europeias, principalmente as sínteses desses debates constantes nas Cartas Patrimoniais, as contribuições latino-americanas, buscando uma maior aproximação com nossa conjuntura socioeconômica, além das nacionais através da atuação dos principais órgãos de proteção como o IPHAN. A seguir, foi dado início à etapa de levantamento, sistematização de dados da área de estudo a partir da coleta de dados 
como bases cartográficas, legislação urbanística e patrimonial além de planos e projetos elaborados para a área junto ao Poder Público Municipal. Visando a construção de uma visão abrangente sobre a área de estudo (diagnóstico) foram levantados diversos dados através de pesquisa bibliográfica, documental, cartográfica, fotográfica, iconográfica, e levantamentos de campo sobre temas como sua história urbana (pesquisa histórica); usos e apropriações, padrões de ocupação do solo (taxa de ocupação, gabarito, alinhamentos); legislação urbanística e patrimonial; estudos e instrumentos de proteção do patrimônio cultural; manifestações culturais; sistema viário; veículos de publicidade dentre outros.

Após a leitura e interpretação desses dados, associadas às importantes contribuições metodológicas para a elaboração de Planos de Preservação presentes em trabalhos como o Programa de Recuperação do Centro Histórico de Salvador (BRAGA, 2009); Programa de Recuperação Orientada (proRIO) - Morro da Conceição (RIO DE JANEIRO, 2000); Plano de Preservação: um instrumento necessário (MERSENTIER, 2007); Planos de Preservação de Sítios Históricos Urbanos: termo geral de referência (BRASIL, 2005); Metodologia para recolhimento de dados de configuração urbana em sítios tombados (KOHLSDORF, 2000), foi possível a elaboração de uma estrutura metodológica adaptada ao Centro Histórico de Angra dos Reis visando à identificação e a preservação de seu patrimônio cultural. Além da proposta metodológica para elaboração do Plano de Preservação, também são propostas ações gerais como: valorização dos espaços livres públicos como ruas e praças, revisão do sistema de gestão patrimonial do município; incentivo ao uso residencial dentre outros.

No recorte escolhido para aplicação da metodologia proposta, os estudos foram aprofundados gerando um grande trabalho de levantamento e sistematização dos dados, diagnóstico e a elaboração de propostas viáveis e justificadas a partir dos dados coletados. A área de estudo abrangeu todos os $460 \mathrm{~m}$ de extensão Rua do Comércio e suas 107 edificações, além das praças: General Osório (2590 m²), Codrato de Vilhena $\left(590 \mathrm{~m}^{2}\right)$ e Silvestre Travassos $\left(575 \mathrm{~m}^{2}\right)$. Na etapa de levantamento foram realizadas pesquisas abrangendo temas como pesquisa histórica e arqueológica, suporte físico, parcelamento e ocupação do solo, tipologias do conjunto edificado, situação fundiária, manifestações culturais, instrumentos normativos, mobiliário urbano e publicidade, patrimônio cultural, levantamento perceptivo tendo como base a metodologia proposta por Maria Elaine Kohlsdorf (2000), dentre outros. Todo esse material possibilitou a criação de um diagnóstico sistematizado através de textos, tabelas, mapas temáticos e principalmente uma representação do perfil de todo o conjunto contendo todos os itens de pesquisa relativos ao conjunto edificado (usos, gabarito, linguagem histórica e estado de conservação) (Figura 3).

Figura 3: Recorte da síntese do levantamento através de perfis das edificações da Rua do Comércio (à esquerda) e um dos mapas temáticos (linguagens históricas) produzidos na etapa de levantamento (à direita).

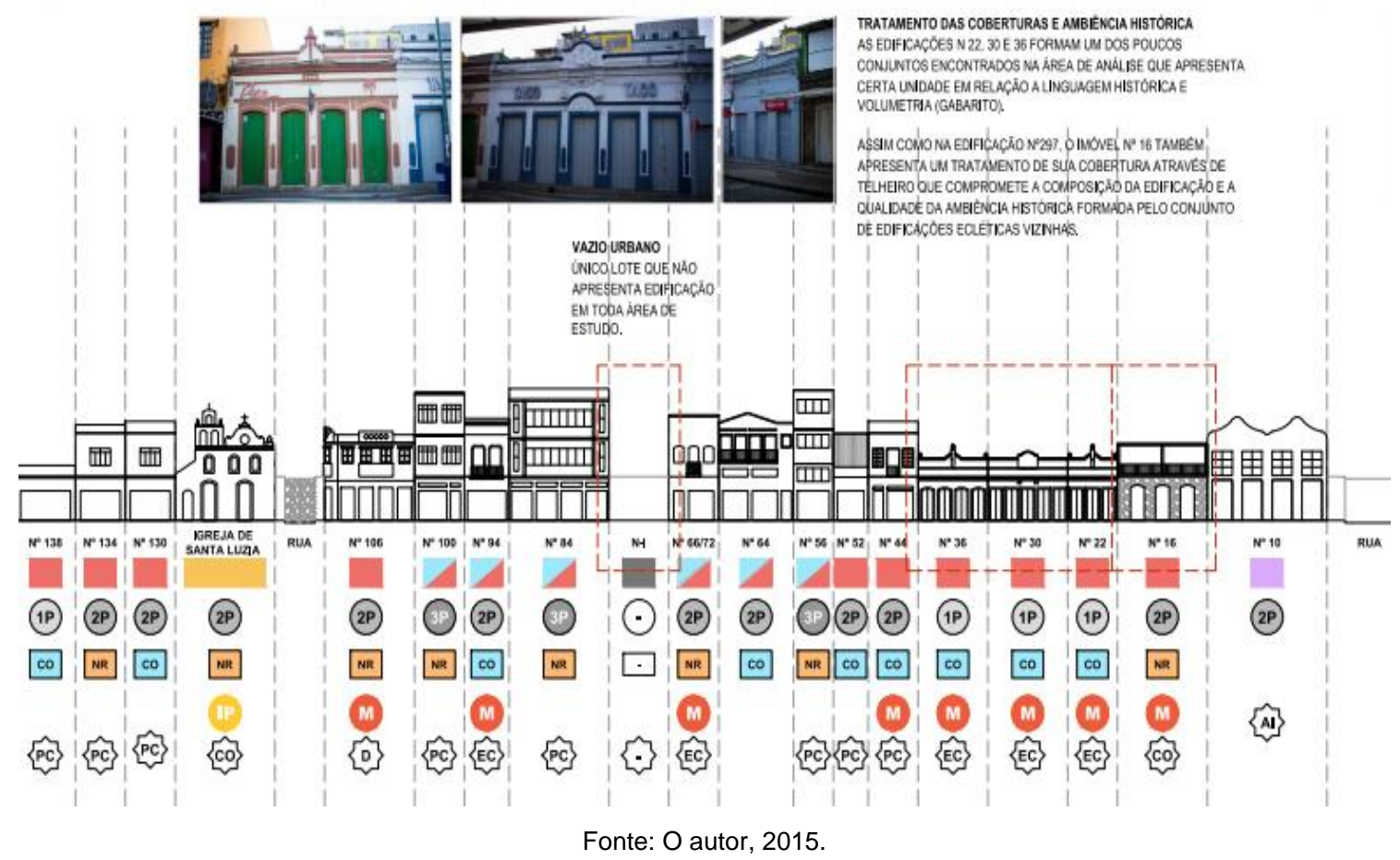

Após a leitura desses dados foram elaboradas as seguintes propostas visando a preservação do patrimônio cultural urbano da área de estudo: 
Proposta 01 - Revisão dos parâmetros urbanísticos exigidos dentro da ZECHAR abrangendo taxa de ocupação, afastamentos, gabarito, altura máxima, parcelamento do solo e posturas edilícias (instalação de letreiros, toldos, equipamentos de ar-condicionado dentre outros).

Proposta 02 - Identificação e seleção dos bens de valor cultural através das categorias de proteção a partir de uma visão contemporânea sobre a conceituação de patrimônio cultural ao incluir nos critérios de seleção não só as linguagens históricas atendidas pelo Decreto 432/93 (colonial, eclético, Arte Déco), mas também os exemplares modernistas e a produção arquitetônica de caráter vernacular e os espaços livres públicos como as praças. Também é proposta a classificação desses bens em categorias como imóveis passíveis de tombamento, preservação e tutela, e o fomento a conservação de imóveis no Centro Histórico por meio de incentivos fiscais e a criação de um Fundo Municipal de preservação do Patrimônio Cultural.

Proposta 03 - Projeto de requalificação urbanística da Rua do Comércio (Figura 4) visando a recuperação da identidade cultural da Rua como principal via urbana de Angra dos Reis tendo como principais objetivos: requalificar a paisagem urbana através de elementos como nova pavimentação e mobiliário urbano servindo como elemento disseminador de um processo de recuperação do valor cultural inerente a esta via; valorizar bens de valor cultural através de uma proposta de sinalização composta por totens, maquetes e placas informativas; incentivar a apropriação desta via não só no período diurno como também no noturno através da utilização do logradouro público com mesas e cadeiras de bares e restaurantes.

Figura 4: Mapa e representações dos parâmetros urbanísticos propostos (a esquerda), ficha inventário para seleção dos bens passíveis de proteção (centro) e instruções para instalação de letreiros (a direita).
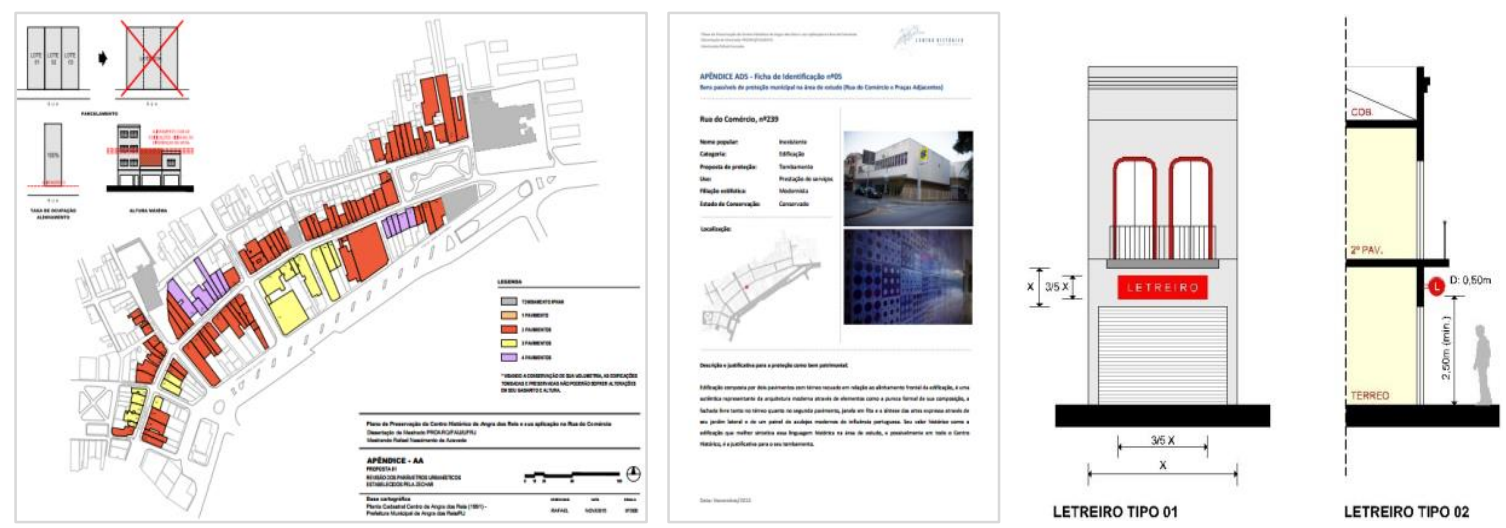

Fonte: O autor, 2015.

Proposta 04 - Inserção da "nova arquitetura" por meio de ações como seminários, oficinas e palestras produzidas em parceria com o poder público municipal, instituições representativas dos arquitetos e urbanistas como o CAU (Conselho de Arquitetura e Urbanismo) e Instituições de Ensino Superior (IES) debatendo junto aos arquitetos da região estratégias projetuais de inserção dessa nova arquitetura respeitando as pré-existências sem cair em soluções como pastiches ou propostas de contraste negativo (Figura 5).

Figura 5: Simulação de nova fachada para o único lote vazio na Rua do Comércio.

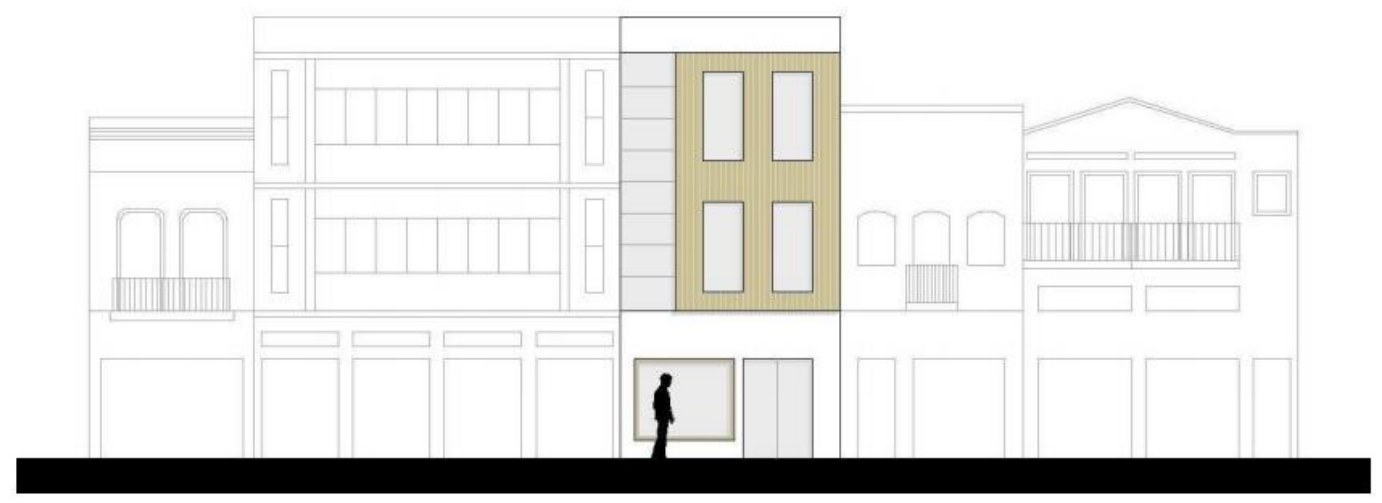

Fonte: O autor, 2015.

Proposta 05 - Projeto de Restauração da Praça General Osório preservando seu valor histórico (praça mais antiga da região) e artístico (Projeto original de Roberto Burle Marx) através de ações como a reconstituição 
das espécies vegetais propostas no projeto original visando resgatar a unidade do projeto paisagístico e implantação de placas com informações históricas.

Proposta 06 - Produção de material gráfico e textual (Portal Patrimônio Cultural). Proposta que tem como objetivo servir como um "projeto piloto" para todo o Centro Histórico. Visa a criação de material gráfico e textual sobre o patrimônio cultural urbano da região Angra dos Reis/RJ e a produção de um portal eletrônico. São exemplos dos produtos a serem produzidos: mapas interativos contendo inventários, mapas temáticos, fotos históricas, infográficos além de maquetes digitais apresentando a evolução urbana da região.

Têm-se como expectativa que este trabalho sirva como um instrumento para que o poder público municipal e a população angrense possam adotar na agenda do desenvolvimento urbano de Angra dos Reis/RJ a preservação de seu patrimônio cultural, principalmente de seu Centro Histórico, área que ainda conserva através de elementos com a forma urbana e exemplares de linguagens históricas da arquitetura, uma importante parcela da história deste município com mais de 500 anos que precisa ser preliminarmente reconhecida e valorizada como um bem de valor cultural para que sua preservação seja garantida. Essas verdadeiras "permanências históricas", marcas dos diversos períodos socioeconômicos pelos quais o município passou, são bens de uma Angra que todo angrense, ou apaixonado por ela, tem o direito de conhecer, vivenciar e proteger.

\section{REFERÊNCIAS}

ALVES FILHO, Deusdedith de Souza. Angra dos Reis: monumentos históricos entre a indústria e o paraíso. Dissertação (Mestrado em Planejamento Urbano e Regional) - Universidade Federal do Rio de Janeiro, Rio de Janeiro, 2004.

AZEVEDO, Rafael Nascimento de. Plano de Preservação do Centro Histórico de Angra dos Reis/RJ e sua aplicação na Rua do Comércio. 2015. Dissertação (Mestrado Profissional em Projeto e Patrimônio) - PROARQ/UFRJ - Programa de Pós-graduação em Arquitetura da Universidade Federal do Rio de Janeiro, Rio de Janeiro, 2015.

BRAGA, P. M. ; SANTOS JUNIOR, W. R. O Programa de Recuperação do Centro Histórico de Salvador e as lições das Cartas Patrimoniais. Arquitextos. São Paulo: Online, v. 107, p. 510, 2009.

BRASIL. Ministério da cultura. Instituto do Patrimônio Histórico e Artístico Nacional. Preservação de Sítio Histórico Urbano: Termo Geral de Referência. Brasília, 2005.

KOHLSDORF, Maria Elaine. Metodologia para recolhimento de dados de configuração urbana em sítios tombados. Brasília: Ministério da Cultura / IPHAN, 2000.

MESENTIER, Leonardo Marques de. Plano de preservação: um instrumento necessário. In: LIMA, Evelyn Furquim Wernec; MALEQUE, Miria Roseira (Org.). Espaço e cidade: conceitos e leituras. Rio de Janeiro: 7 letras, 2007, p. 57-68.

SIGAUD, Márcia F; PINHO, C. Morro da Conceição: da memória o futuro. Rio de Janeiro: Sextante Artes, 2000.

NOTA DO EDITOR (*) O conteúdo do artigo e as imagens nele publicadas são de responsabilidade do(s) autor(es). 


\section{REVITALIZAÇÃO DO CINE ORLY: "ESPAÇO SÃO CARLOS" DE APOIO À CULTURA CINEMATOGRÁFICA}

\section{FERREIRA, IZABELLA DE SOUZA BARRETO RAMOS}

Arquiteta, MsC., email: izabellabarreto.arq@gmail.com

Dissertação desenvolvida no Mestrado Profissional em Projeto e Patrimônio. PROARQ/UFRJ -

Programa de Pós-graduação em Arquitetura da Universidade Federal do Rio de Janeiro.

Orientadora: Maria Lygia A. Niemeyer; Coorientadora: Rosina Trevisan M. Ribeiro

\section{RESUMO EXPANDIDO}

A proposta de revitalização do Cine Orly, desenvolvida para o programa do Mestrado Profissional em Projeto e Patrimônio da Universidade Federal do Rio de Janeiro, se baseou nas discussões constantes sobre a necessidade de preservação do patrimônio e inserção do mesmo em seu contexto urbano e social, tendo como proposta a valorização da arquitetura dos antigos cinemas, através da preservação da tipologia das salas de projeção.

Os antigos cinemas de rua são interessantes objetos de estudo. Suas diferentes tipologias arquitetônicas, que foram se reformulando e atualizando com o passar dos anos, mostram que sua volumetria apresenta-se relevante não apenas por suas características materiais, sendo também passiveis de preservação por detalhes espaciais, que podem vir a se sobrepor a riqueza dos elementos que adornavam os denominados "palácios" (GONZAGA, 1996).

O objeto cinematográfico escolhido para estudo foi o Cine Orly, denominado como "poeira" (GONZAGA, 1996), ou cinemas de menor porte. Localizado no subsolo do Edifício Teatro Regina, igualmente conhecido no ramo das artes por também abrigar o Teatro Dulcina, este pequeno cinema está localizado na Rua Alcindo Guanabara, na região da Cinelândia, importante espaço urbano do centro da cidade do Rio de Janeiro, e referência histórica quanto ao desenvolvimento dos cinemas de rua local.

Exemplares arquitetônicos do quanto a sociedade se apropria e interfere na concepção de alguns tipos de edificações de caráter público, os cinemas de rua, independente do porte de suas salas de projeção, acabaram por se descaracterizar, sendo transformados em igrejas, lojas, ou outros cinemas subdivididos em numerosas salas, de forma que poucas são as unidades que ainda apresentam resquícios de sua formação arquitetônica inicial.

Portanto, o ponto de partida para a construção da proposta e definição das metodologias projetuais a serem abordadas, foi a conceituação para preservação através da pesquisa histórica tanto da Cinelândia e do Cine Orly, quanto de seu entorno imediato. Em seguida, foi realizado, além do levantamento físico e análise completa do espaço, incluindo a análise acústica do existente, o estudo das diferentes tipologias de salas de cinema existentes atualmente no Rio de Janeiro, para comparações de programa, materialidade e volumetria.

O embasamento teórico para o projeto deu-se através de dois questionamentos: "Por que preservar?", e "Como preservar/ intervir?". Seguindo os conceitos ditados por Riegl (2013) no início do Século XX e afirmados por Choay (2006), onde a obra em questão se afirma como não intencional, de valor histórico e com potencialidade para preservação por seu Valor de Memória, o projeto apresentado visou a consolidação do espaço hoje existente, sem pretensão de intervir de forma a resgatar a materialidade e espacialidade de outrora.

Tal postura igualmente é discutida por Kühl (2012, p. 4), quando a mesma afirma a necessidade de "[...] analisar a obra e o ambiente (físico, sociocultural e econômico), historicamente estratificados e considerálos como dados de projeto.". Ainda seguindo os postulados de Riegl, a conclusão teórica entendeu que a potencialidade para preservação se deu pelo seu Valor de Memória, mas que, ao intervirmos, o cinema reivindicará para si Valor de Atualidade, devido ao valor de uso que foi agregado ao mesmo.

Já a resposta para "Como preservar/ intervir?", veio após essa primeira conceituação sobre as potencialidades de preservação, onde, ao analisarmos sua arquitetura de forma detalhada, podemos identificar pequenas modificações e adaptações que se faziam necessárias para utilização segura e eficaz 
do espaço, e principalmente, para resguardo das características físicas que tornaram este espaço um interessante objeto a ser preservado.

Carsalade (2011) descreve "[...] a preservação não está na capacidade do bem em permanecer como está, mas na sua capacidade de mudar junto com as mudanças socioculturais.", então, seguindo as diretrizes já amplamente defendidas pelos teóricos ligados à preservação patrimonial, destacou-se em todo o projeto a integração da tríade de Brandi (2004) - Distinguibilidade, Mínima Intervenção e Reversibilidade, assim como os postulados da Carta de Veneza (I: CURY, 2000), para a obtenção do projeto apresentado, conforme resumo exposto na figura 1:

Figura 1: Diretrizes conceituais para formulação da proposta e intervenção.

\begin{tabular}{|c|c|}
\hline CESARE BRANDI & CARTA DE VENEZA \\
\hline $\begin{array}{l}\text { Distinguibilidade } \\
\text { [...] que a integração deverá ser sempre e } \\
\text { facilmente reconhecível, mas sem que para isso se } \\
\text { venha a infringir a própria unidade que se visa } \\
\text { reconstruir. }\end{array}$ & $\begin{array}{l}\text { Artigo 9: [...] no plano das reconstituições } \\
\text { conjecturais todo o trabalho complementar } \\
\text { reconhecido como indispensável por razões } \\
\text { estéticas ou técnicas destacar-se-á da composição } \\
\text { arquitetônica e deverá ostentar a marca do nosso } \\
\text { tempo. }\end{array}$ \\
\hline $\begin{array}{l}\text { Mínima Intervenção } \\
\text { Dois axiomas - intervenções não devem, jamais, } \\
\text { se sobrepor ao monumento, e devem ser } \\
\text { realizadas apenas quando necessário, de forma a } \\
\text { resguardar a unidade potencial da obra. }\end{array}$ & $\begin{array}{l}\text { Artigo 12: Os elementos destinados a subsistir as } \\
\text { partes faltantes devem reintegrar-se } \\
\text { harmoniosamente ao conjunto, distinguindo-se, } \\
\text { todavia, das partes originais a fim de que a } \\
\text { restauração não falsifique o documento de arte e } \\
\text { de história. }\end{array}$ \\
\hline $\begin{array}{l}\text { Reversibilidade } \\
\text { [...] qualquer intervenção de restauro não torne } \\
\text { possivel mas, antes, facilite as eventuais } \\
\text { intervenções futuras. }\end{array}$ & $\begin{array}{l}\text { Artigo 13: Os acréscimos só poderão ser tolerados } \\
\text { na medida em que respeitarem todas as partes } \\
\text { interessantes do edifício, seu esquema tradicional, } \\
\text { o equilibrio de sua composição e suas relações com } \\
\text { o meio ambiente. }\end{array}$ \\
\hline
\end{tabular}

Fonte: O autor, 2016.

Paralelamente ao entendimento sobre preservação, foi discutida a necessidade da interdisciplinaridade efetiva em projetos de recuperação de bens de valor patrimonial, e a partir dessas constatações, o trabalho apresenta o estudo acústico como uma disciplina viável na determinação de diretrizes de mínima intervenção em espaços como salas de cinema.

O trabalho conjunto e contínuo entre os dois condicionantes principais discutidos (teoria para preservação e preceitos acústicos) possibilitou um entendimento completo de todos os aspectos materiais e volumétricos, e constatou as qualidades e defeitos acústicos para o novo uso especificado, direcionando assim as intervenções de forma racional e objetiva.

De forma geral, o projeto visa à preservação do atual Cine Orly, a partir da transformação do mesmo em Espaço São Carlos (denominação do cinema na década de 1940), e teve como base para formação do novo uso, o conceito cineclubista de espaço para apreciação e debate sobre cinemas e seus aspectos.

O programa arquitetônico concebido teve como objetivo torná-lo um local de projeção e armazenamento de filmes já digitalizados, em conformidade com as necessidades locais de acervo divulgadas pelos órgãos competentes à cultura cinematográfica brasileira, mas além do uso para projeções, o espaço igualmente poderá ser aproveitado como ponto de palestras, contando também com um café/bar para ser utilizado pelo público local.

As intervenções, ao apreciar as diretrizes de mínima intervenção e respeito ao conjunto edificado, foram limitadas ao perímetro compreendido entre a Sala de Projeção e a Sala do Projetor, estando os cômodos ao redor passíveis de modificações físicas, quando necessário.

A Sala de Projeção em si, apresenta volumetria interessante, e tornou-se o foco do estudo, mas para novo uso. Por apresentar características não condizentes com os novos padrões de conforto geométrico acústico, algumas modificações foram propostas para adequação e modernização do espaço, como, a substituição das fileiras de cadeiras tradicionais, por uma organização mais despojada, formada por mesas com cadeiras, poltronas e sofás.

O espaço da Sala de Projeção atualmente apresenta-se subdivido em 03 áreas, sendo que uma é delimitada pelo balcão, e as outras duas pelo salão principal, que é institivamente dividido por apresentarem 
duas inclinações de piso distintas, portanto, como diretriz de projeto, as três áreas já delimitadas foram mantidas, e zoneadas com diferentes usos, fato que direcionou suas intervenções (Figura 2).

Figura 2: Zoneamento das diferentes ocupações da sala de projeção do Cine Orly

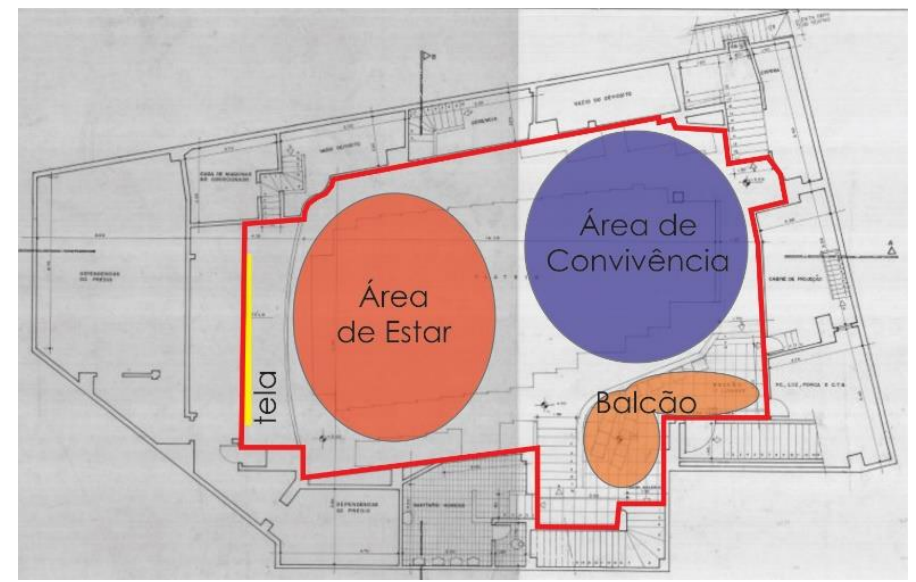

Fonte: Intervenção sobre desenho arquitetônico cedido pela família Valansi, atual proprietária do estabelecimento.

$\mathrm{A}$ área correspondente à proximidade com a Tela de Projeção, por apresentar uma menor inclinação no piso, tornou-se Área de Estar, através da implantação de sofás e poltronas, corroborando ao conceito de mínima intervenção de Brandi (2004), já para área de maior inclinação, foi proposta a construção de uma plataforma removível, que possibilitaria a planificação do piso e seu consequente uso seguro, chegando assim ao projeto de Área de Convivência através da implantação de mesas e cadeiras. Por fim, a área do balcão manteve-se, com da retirada das cadeiras e o acréscimo em seu peitoril de uma estrutura independente, similar aos balcões de bar.

Figura 3: Estudo da curva de visibilidade da proposta e da plataforma para nivelamento da sala.

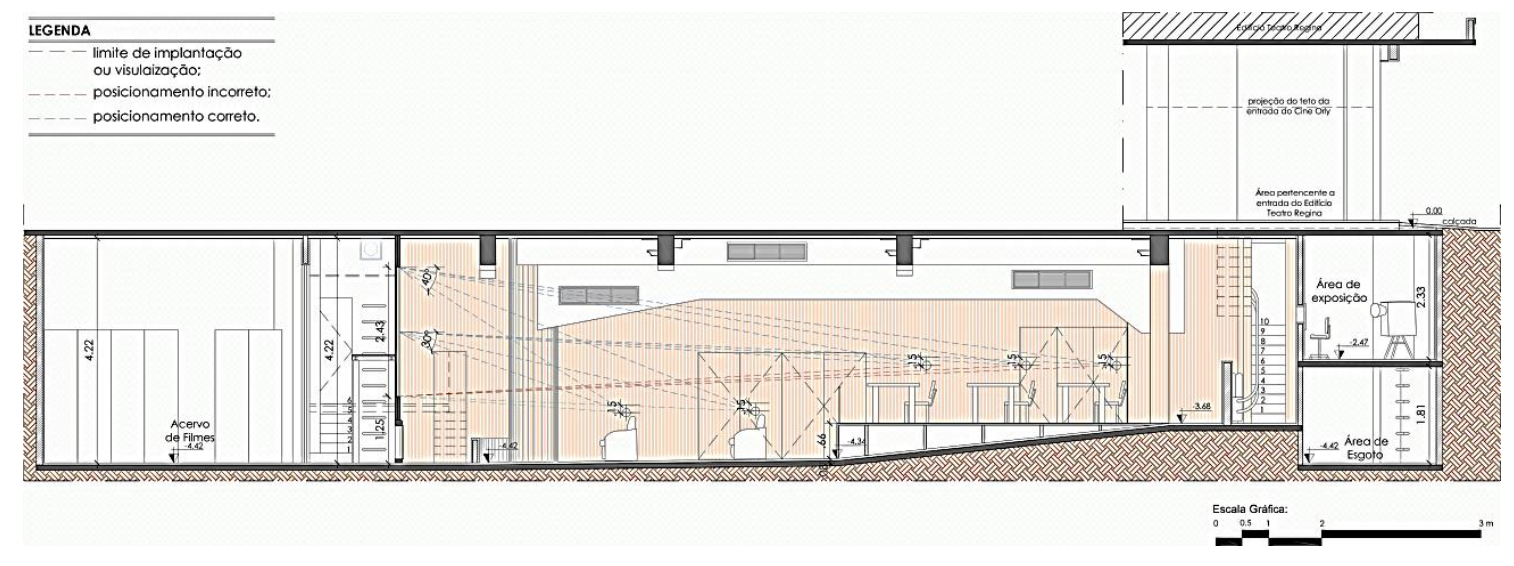

Fonte: Projeto da autora, 2016.

A metodologia utilizada para intervenção após o zoneamento inicial da sala foi o estudo acústico do recinto, sendo este dividido em duas etapas. Primeiro, foi realizado o estudo geométrico acústico da nova sala proposta, para averiguação das condições ergonômicas das modificações propostas, concluindo que houve uma adequação eficaz da Curva de Visibilidade, e implantação das poltronas e do projetor.

A segunda etapa diz respeito ao tratamento acústico do recinto, que através de cálculos específicos e medições in loco, nos indicou os Tempos de Reverberação da sala, e como se chegar a uma acústica de qualidade.

Além das considerações técnico-acústicas e teórico-metodológicas, as intervenções foram basicamente geridas pela materialidade do espaço, pois é através desses que é visto os índices de absorção e reflexão dos revestimentos. No caso da proposta chegou-se a conclusão que, além do cobrimento do piso por carpete, a melhor solução seria a aplicação de placas acústicas no teto (rebaixo parcial por nuvens acústicas), e a substituição das ripas de madeira da parede, atualmente encontradas no local, por novas, de tamanho e coloração similares, mas com propriedades acústicas.

Em resumo, a proposta final manteve a ambiência e a volumetria das salas de projeção, ao mesmo tempo em que destacou as intervenções, como forma de respeitar ainda mais o historicismo estético do ambiente, 
por fim, foi realizado o estudo cromático da sala, pois ambientes relacionados com projeções devem sempre apresentar materiais que possibilitem o contraste entre as superfícies e a projeção (Figuras 3 e 4). A escala cromática encontrada foi respeitada na intervenção apresentada.

Figura 4: Vista da Plateia atual.

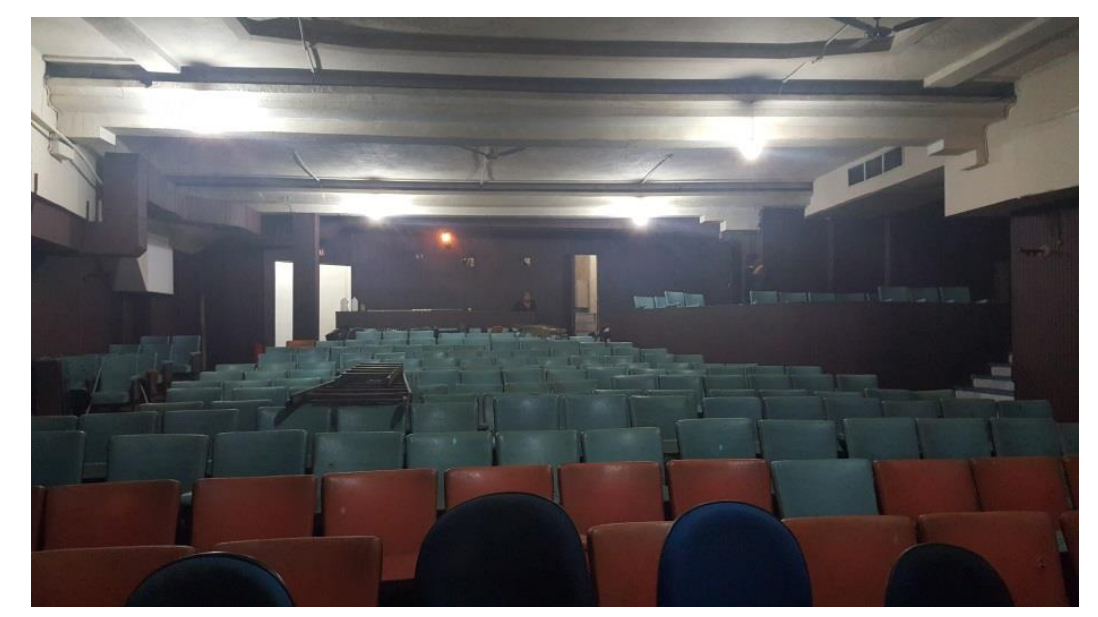

Fonte: Foto da autora, 2015.

Figura 5: Plateia - Proposta de Intervenção

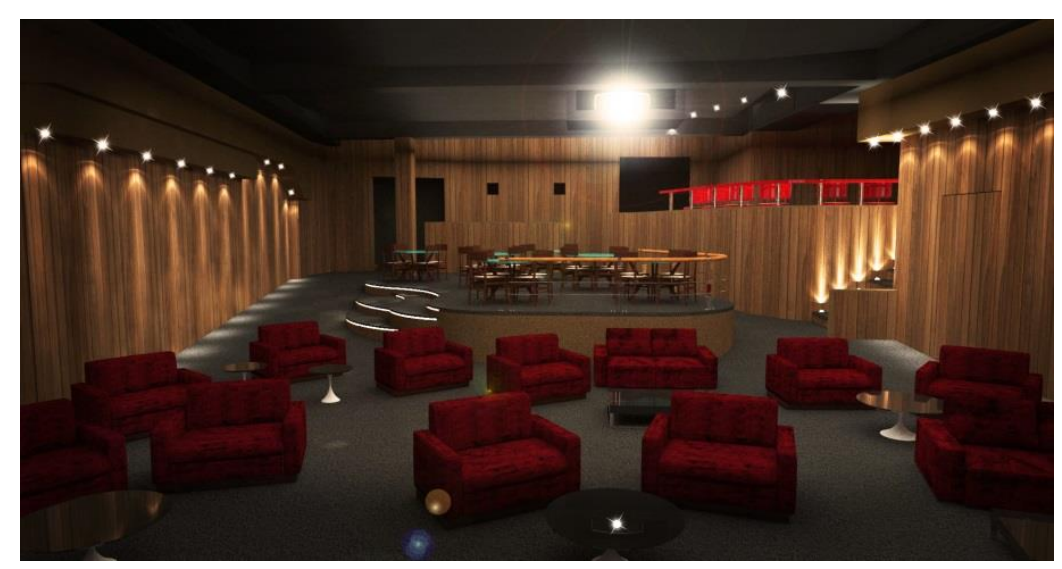

Fonte: Projeto da autora, 2015.

O segundo ambiente estudado foi a Sala do Projetor, que, de acordo com o estudo geométrico acústico para projeção analógica realizado na parte inicial do projeto, está em conformidade com as normas específicas, mas como a proposta tem como objetivo as projeções com qualidade digitais de som e imagem, o cômodo da sala do projetor, ou 'cabine de projeção', entrou em desuso, portanto, seu ponto no projeto específico foi transformado em um espaço rememorativo à história do próprio Cine Orly.

Nesse ambiente, além de exposições dos dois projetores originais ainda encontrados no cinema, os usuários igualmente poderão vivenciar a experiência dos antigos projetistas visualizando a história do Cine Orly através de vídeos projetados em câmaras escuras inseridas nas duas aberturas de projeção (locais ode ficavam posicionados os projetores) originais da sala.

Por fim, em todos os ambientes do cinema, as normas de segurança e acessibilidade foram levadas em consideração, chegando-se a nova lotação média de 45 lugares, distribuídos pelos três ambientes diferenciados explicitados anteriormente, que estão inseridos no mesmo espaço e sem barreiras físicas consideráveis, sendo estes: 15 lugares na Área de Estar, 24 lugares na Área de Convivência e 06 lugares no Balcão (Figuras 5 e 6). 
Figura 6: Balcão da Sala de Projeção existente

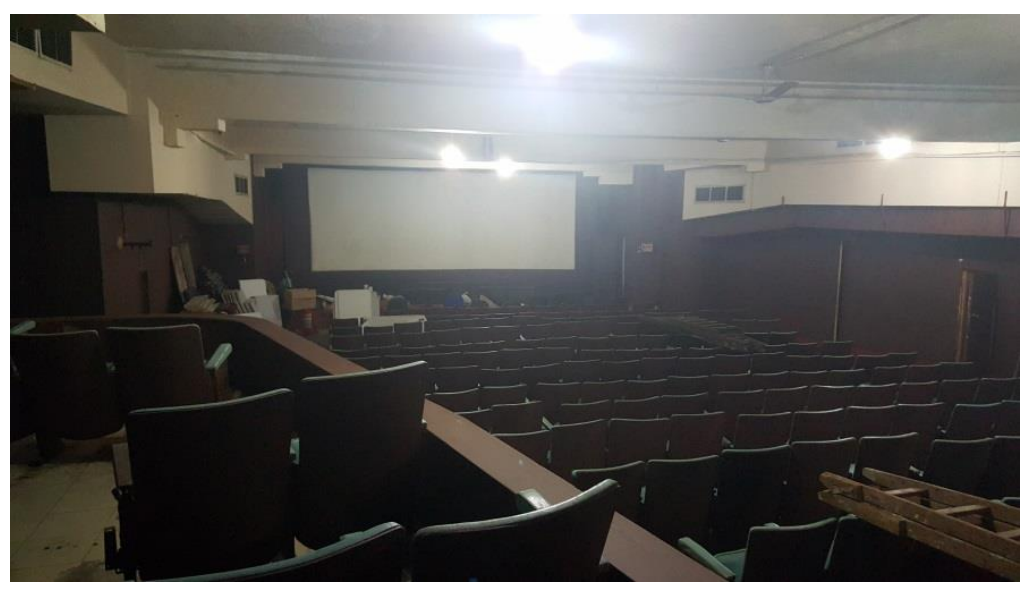

Fonte: Foto da autora, 2015.

Figura 7: Proposta de Intervenção no Balcão da Sala de Projeção

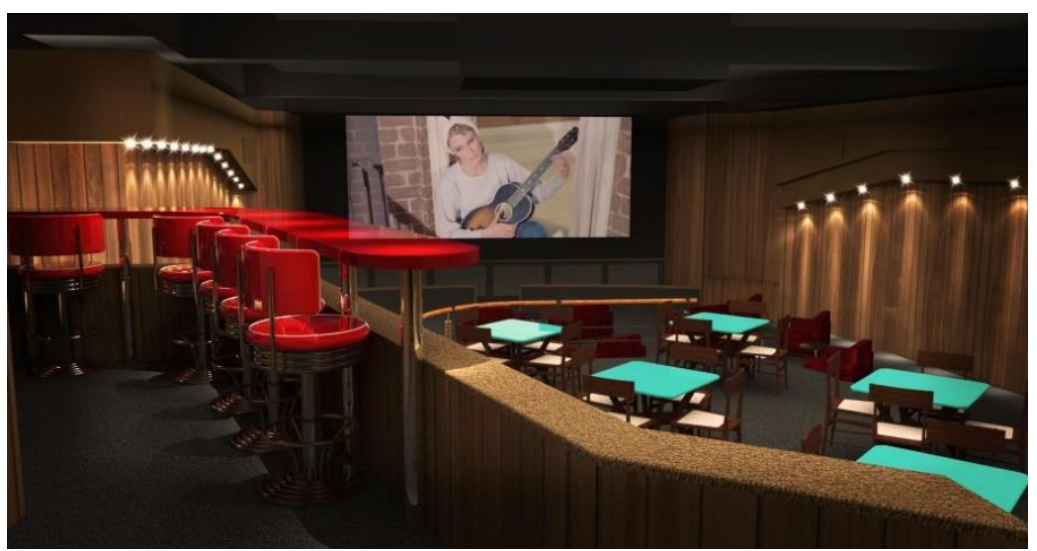

Fonte: Projeto da autora, 2015.

\section{REFERÊNCIAS}

BRANDI, Cesare. Teoria da Restauração. Trad. Beatriz M. Kühl. São Paulo: Ateliê Editorial, 2004.

CARSALADE, Flávio de Lemos. A preservação do patrimônio como construção cultural. São Paulo: Arquitetextos, 2012. CHOAY, Françoise. A Alegoria do Patrimônio. Trad. Luciano Vieira Machado. 3a ed. - São Paulo: UNESP, 2006.

CURY, Isabelle. Cartas Patrimoniais. Rio de Janeiro: IPHAN, 2000.

FERREIRA, Izabella de S. B. R.. Revitalização do Cine Orly: Espaço São Carlos de apoio à cultura cinematográfica. Dissertação (Mestrado Profissional em Projeto e Patrimônio) - PROARQ/UFRJ - Programa de Pós-graduação em Arquitetura da Universidade Federal do Rio de Janeiro, Rio de Janeiro, 2016.

GONZAGA, Alice. Palácios e Poeiras. 100 anos de cinemas no Rio de Janeiro. Editora Record. Rio de Janeiro: Ministério da Cultura, Funarte, 1996.

KÜHL, Beatriz M. Projetos de intervenção em bens arquitetônicos de interesse cultural: por um diálogo construtivo entre o novo e a preexistência. Natal: 2012.

RIEGL, Alois. O Culto Moderno dos Monumentos. Trad. João Tiago Proença. Lisboa: Edições 70, 2013.

NOTA DO EDITOR (*) O conteúdo do artigo e as imagens nele publicadas são de responsabilidade do(s) autor(es). 


\title{
VALORIZAÇÃO DO PATRIMÔNIO: PLANO DIRETOR DE ILUMINAÇÃO URBANA DO CENTRO HISTÓRICO DE PORTO ALEGRE/RS
}

\author{
LISBOA, GISELE PELLEGRINI \\ Arquiteta, MsC., e-mail: giselelisboa@yahoo.com.br. \\ Dissertação desenvolvida no Mestrado Profissional em Projeto e Patrimônio. PROARQ/UFRJ - \\ Programa de Pós-graduação em Arquitetura da Universidade Federal do Rio de Janeiro. \\ Orientadora: Rosina Trevisan M. Ribeiro
}

\section{RESUMO EXPANDIDO}

O objetivo principal da dissertação desenvolvida no Mestrado Profissional em Projeto e Patrimônio da Universidade Federal do Rio de Janeiro foi elaborar diretrizes para um Plano Diretor de iluminação urbana do centro histórico de Porto Alegre, que inserisse o patrimônio na paisagem noturna, valorizando as ambiências históricas e assim atraindo o olhar da população para esta área tão importante da cidade. Entretanto, o objetivo não foi desenvolver um projeto técnico de iluminação, mas criar um plano diretor de iluminação que valorizasse o patrimônio e servisse de base para o desenvolvimento de projetos técnicos de iluminação urbana que sejam viáveis e eficientes em relação à energia.

Para a criação do Plano de lluminação, os estudos se desenvolveram a partir da pesquisa histórica sobre a origem da cidade de Porto Alegre, fundada oficialmente em 1772, com perímetro significativo do seu Centro Histórico tombado a nível federal (Figura 1), com a delimitação da área para aplicação das diretrizes do plano, baseada na área de atuação do Programa Monumenta, que promovia a melhoria das condições dos sítios históricos urbanos. Também foi estudada a história da iluminação, onde foi feito um breve estudo iconográfico (Figura 2) para conhecer os equipamentos de iluminação do centro histórico, além de um levantamento tanto dos equipamentos atuais, como da aparência e ambiências criadas atualmente pela luz na área.

Figura 1: Mapa do bairro Centro Histórico com os bens tombados em todas as instâncias.

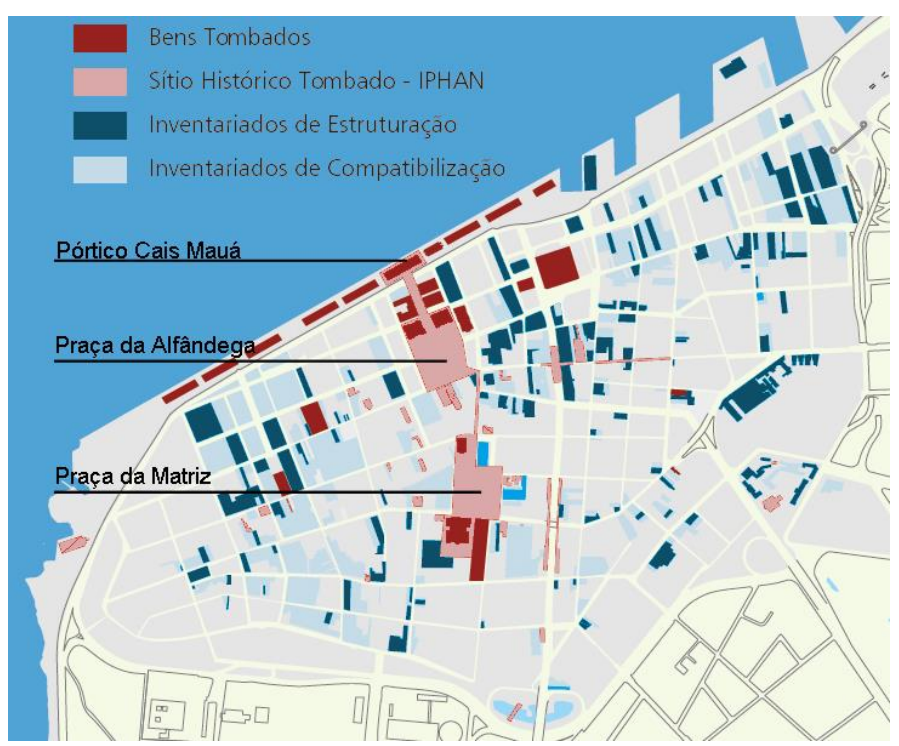

Fonte: Viva o Centro, s/d, editado pela autora, 2015. 
Lisboa, G. P.

Figura 2: Rua dos Andradas, em frente à Praça da Alfândega, iluminada com o sistema "Nova-Lux" entre as décadas de 1950 e 1960.

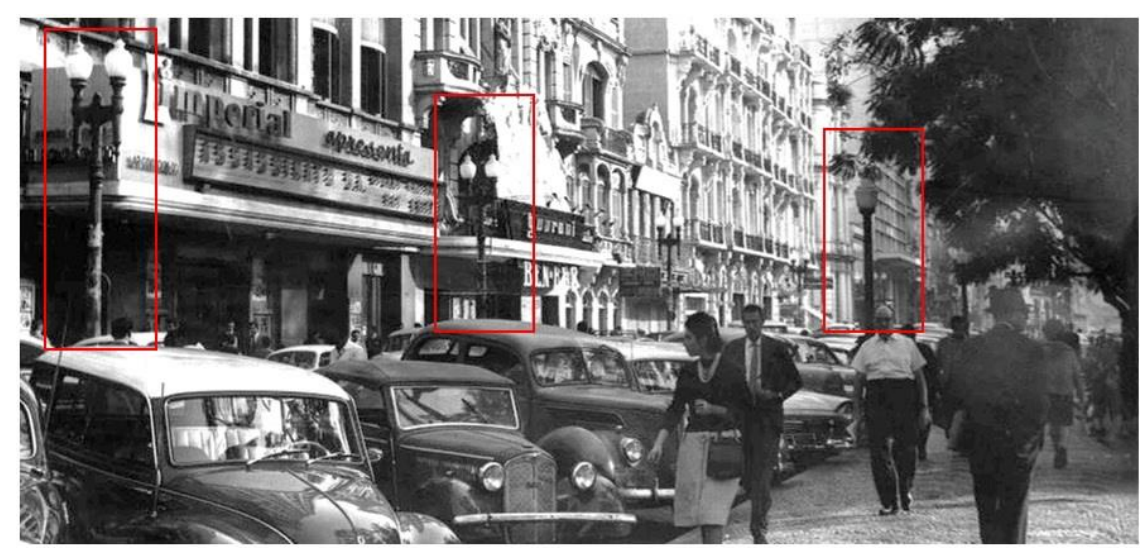

Fonte: Página do Facebook Porto Alegre (fotos Antigas), s/d.

Para a análise da iluminação existente no centro histórico foi utilizada a categorização da iluminação de ambientes urbanos da autora Diana Del-Negro (2012) onde podemos separá-la conforme a escala da envolvente e do edifício. Na escala da envolvente, foi destacada a iluminação uniforme ou funcional (que se caracteriza por apresentar níveis e temperaturas de cor uniformes, que corresponde à maioria das iluminações das cidades) e a iluminação publicitária (grandes superfícies publicitárias iluminadas), que são as que se encontravam basicamente no centro histórico de Porto Alegre.

Já na escala do edifício, eram poucos os que possuíam iluminação nas fachadas na área do recorte. A paisagem noturna não destacava os edifícios importantes, e apagava a ambiência que poderia ser criada pelas edificações históricas que podem ser encontradas distribuídas por toda a área.

A importância dos planos de iluminação foi abordada, pois a iluminação urbana da maior parte das cidades atualmente não contempla o patrimônio, apagando assim um pedaço de sua história durante a noite. Em muitos casos, os edifícios históricos têm apenas as suas fachadas iluminadas, geralmente com uma iluminação cênica ou muito intensa, ou seja, não há um pensamento no conjunto e há uma desvalorização como conjunto histórico, pois em nenhum momento se pensa nesse contexto como uma ambiência histórica e nem mesmo se tem uma identidade noturna.

Os conceitos de ambiência histórica e identidade noturna utilizados são da autora Ana Lúcia Gonçalves (2005), que em sua tese de doutorado produziu o plano diretor de iluminação do bairro histórico de Paraty. Apesar de a autora não definir o conceito de identidade noturna, durante o texto é possível compreender que são as características que estão na memória que fazem deste lugar o que ele é, ou seja, a aparência que a noite e a luz dão ao lugar.

[...] é importante esclarecer o conceito de ambiência, aqui interpretada como o espaço urbano organizado e aparelhado para abrigar as atividades humanas, caracterizada por um meio físico, estético e psicológico impregnado de afetividade, simbologia, sentido e significado para a comunidade. O conjunto de elementos e fatores constituinte da ambiência do lugar é formado pela configuração urbana, pela arquitetura, pelas funções do setor urbano, pelos pólos de animação da vida cotidiana, pelos usos, pelas atividades da área, pelas manifestações culturais, pela paisagem natural e artificial (GONÇALVES, 2005, p. 30).

Além disso, os planos de iluminação têm sido usados estrategicamente em diversas cidades para melhorar a aparência noturna, conferir mais segurança e ordenar a luz no ambiente urbano; nas cidades históricas esses planos adquirem ainda mais importância por conseguirem através deles valorizar o patrimônio. Por este motivo, cidades históricas como Évora em Portugal e Paraty no Brasil, após os primeiros e mais conhecidos planos franceses, especialmente o de Lyon, desenvolveram e aplicaram planos de iluminação para transformar e melhorar sua paisagem noturna.

O plano diretor de iluminação de Porto Alegre, proposto nesta dissertação, teve como base a metodologia (Figura 3) que a arquiteta Ana Lúcia Gonçalves (2005) produziu na tese do seu doutorado, que também serviu para o desenvolvimento do Plano diretor de lluminação de Paraty. 
Lisboa, G. P.

Figura 3: Fluxograma da metodologia para elaboração de planos diretores de iluminação urbana de conjuntos históricos e tradicionais da arquiteta Ana Lúcia Gonçalves.

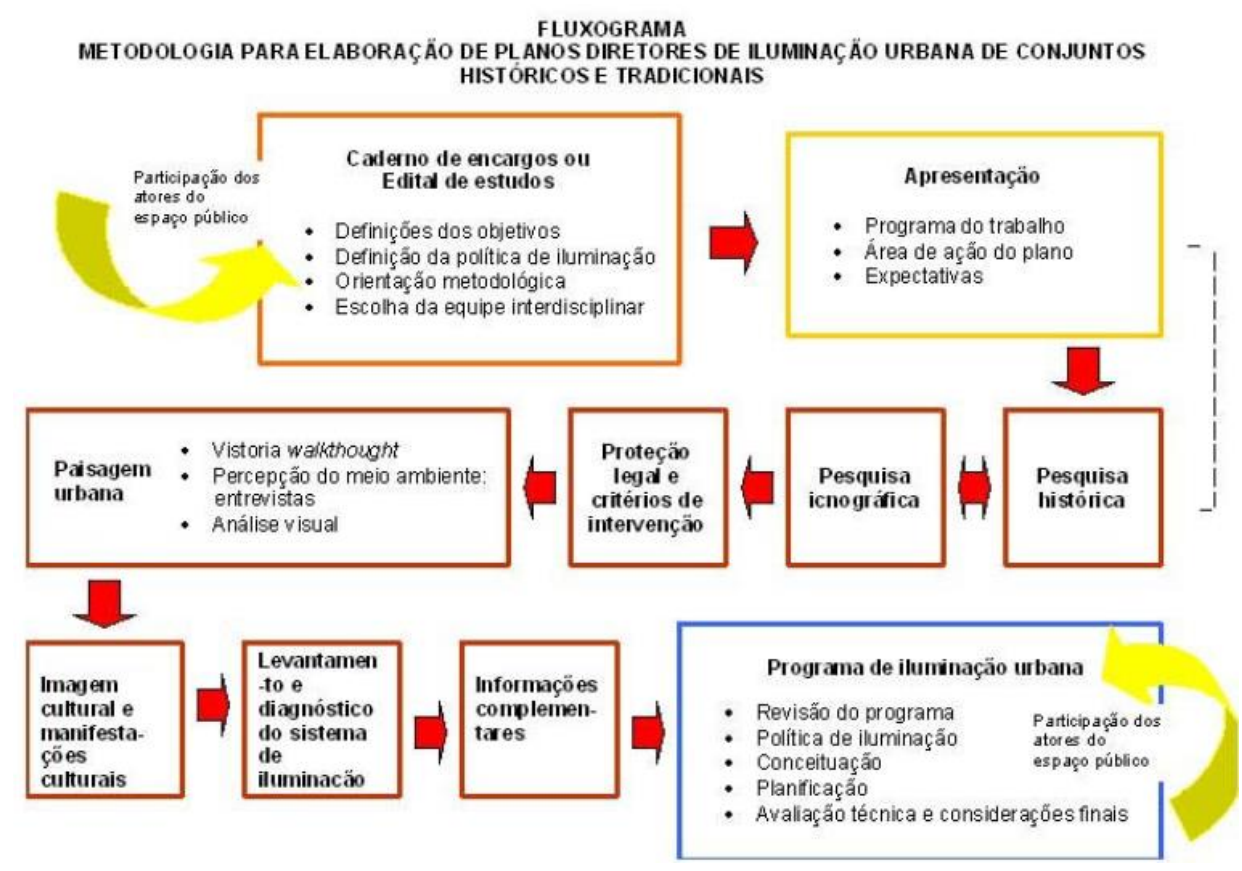

Fonte: GONÇALVES, 2005.

O Plano de lluminação para Porto Alegre foi elaborado com as indicações gerais para quatro áreas separadas dentro do recorte e também o projeto detalhado para a área da Praça da Alfândega, uma das mais antigas da cidade. Este plano tem como objetivo pensar de forma integrada a iluminação urbana para o conjunto do centro histórico, iluminando as ambiências que revelam o espírito do lugar, valorizando o conjunto e utilizando a imagem diurna como referência para selecionar os pontos de orientação para o observador, estabelecendo hierarquias entre os elementos arquitetônicos e urbanos. O plano contém diretrizes para criar a imagem e as ambiências desejadas para a paisagem noturna, além de parâmetros técnicos e operativos para iluminação da cidade quando necessários para o resultado final.

O tipo de iluminação proposto nas diretrizes para o sistema de iluminação pública e para as fachadas das edificações criarão uma identidade noturna específica que retoma a ambiência histórica, valorizando o espaço aberto e as edificações como patrimônio histórico, buscando trazer a memória do lugar.

Esta identidade está baseada na utilização de iluminação mais quente e acolhedora (como as fontes de luz mais antigas) nas áreas que são mais significativas historicamente e na utilização de postes históricos como bens integrados para criar a ambiência noturna histórica e reforçar a paisagem diurna, assim como na utilização de postes contemporâneos com luz neutra que dialogam com os postes históricos e em nenhuma circunstância criando falsos históricos (Figura 4).

O Plano Diretor de lluminação Urbana do Centro Histórico de Porto Alegre buscou valorizar os percursos e visuais mais importantes, sem descontextualizar as edificações históricas do entorno. A partir dos conceitos de Lynch (1960), foi possível iluminar a cidade para o observador, ou seja, iluminando os caminhos, os marcos, reforçando os nós e as características de cada área (Figura 5). O fato de ser desenvolvido para uma área que já está em processo de revitalização, por ter participado do Programa Monumenta, reforça a relação de planejamento e integração de planos, pois juntos eles podem transformar a cidade de forma mais completa e com maior garantia na aplicação dos mesmos. 
Figura 4: Mapa das temperaturas de cor e pontos luminosos.

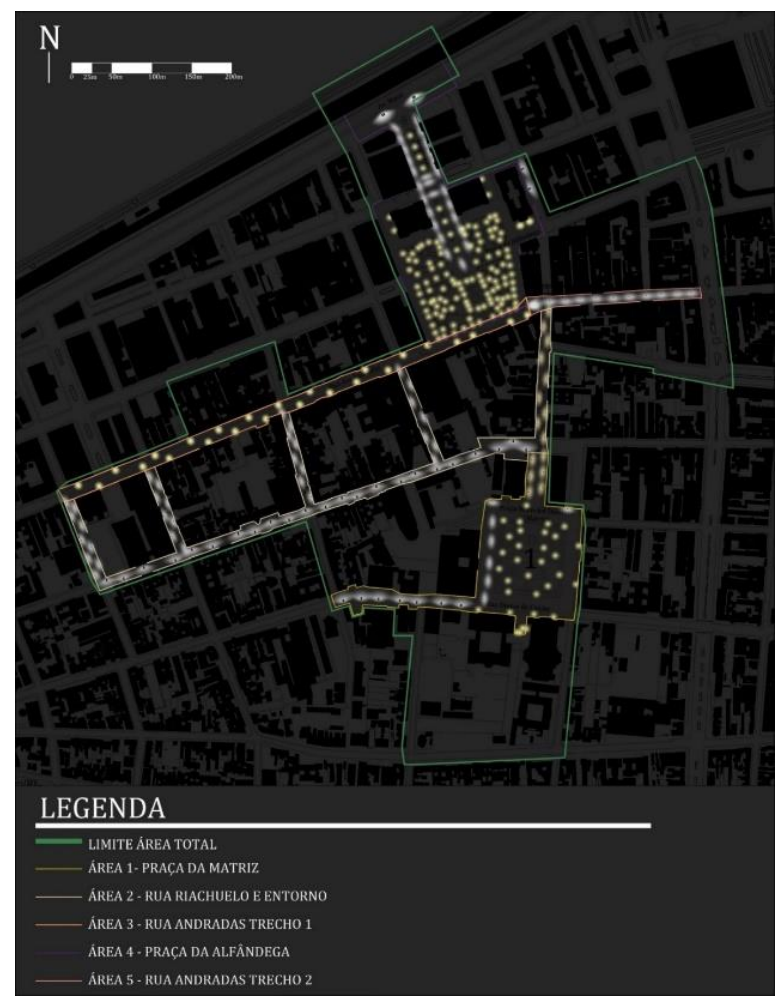

Fonte: Produzido pela autora, 2016.

Figura 5: Renderização mostrando a aplicação do plano diretor na área 04 - Praça da Alfândega.

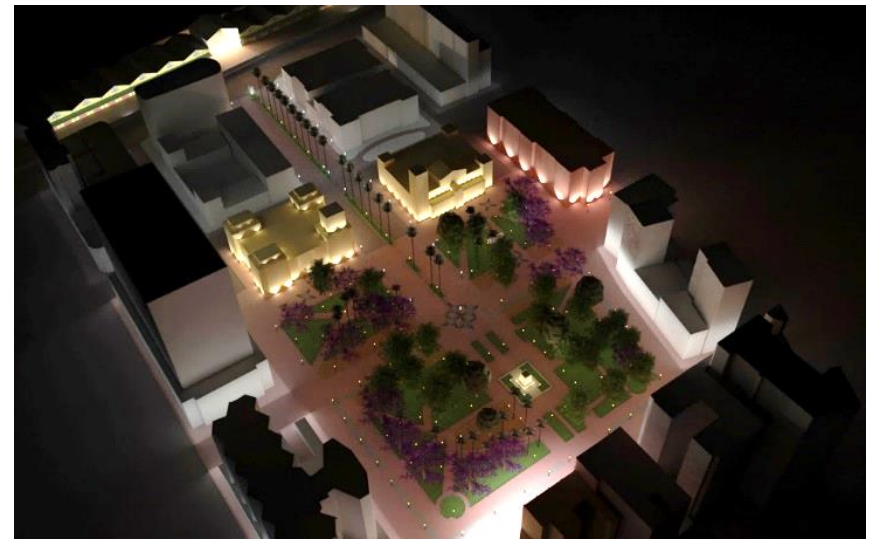

Fonte: Figura produzida pela autora, 2016.

\section{REFERÊNCIAS}

DEL-NEGRO, D. Arquitectura em Luz - A iluminação exterior do Patrimônio. Casal de Cabra: Caleidoscópio, 2012.

GONÇALVES, A. L. D. A. Iluminação Urbana em Conjuntos Históricos Tradicionais. Adequação do projeto à ambiência. Uma metodologia para planos diretoresde iluminação. O caso do bairro histórico de Paraty. Tese de Doutorado Faculdade de Arquitetura e Urbanismo, Universidade de São Paulo. São Paulo. 2005.

LISBOA, Gisele Pellegrini. Valorização do Patrimônio: Plano diretor de iluminação urbana do Centro Histórico de Porto Alegre/RS. 2016. Dissertação (Mestrado Profissional em Projeto e Patrimônio) - PROARQ/UFRJ - Programa de Pósgraduação em Arquitetura da Universidade Federal do Rio de Janeiro, Rio de Janeiro, 2016.

LYNCH, K. A Imagem da Cidade. Tradução de Maria Cristina Tavares Afonso. Lisboa: Edições 70, 1960.

NOTA DO EDITOR (*) O conteúdo do artigo e as imagens nele publicadas são de responsabilidade do(s) autor(es). 